\title{
Single domain antibodies for the knockdown of cytosolic and nuclear proteins
}

\author{
Thomas Böldicke* \\ Helmholtz Centre for Infection Research, Structure and Function of Proteins, Inhoffenstraße 7, D-38124, Braunschweig, \\ Germany
}

Received 3 February 2017; Accepted 3 March 2017 DOI: 10.1002/pro.3154

Published online 8 March 2017 proteinscience.org

\begin{abstract}
Single domain antibodies (sdAbs) from camels or sharks comprise only the variable heavy chain domain. Human sdAbs comprise the variable domain of the heavy chain (VH) or light chain (VL) and can be selected from human antibodies. SdAbs are stable, nonaggregating molecules in vitro and in vivo compared to complete antibodies and scFv fragments. They are excellent novel inhibitors of cytosolic/nuclear proteins because they are correctly folded inside the cytosol in contrast to scFv fragments. SdAbs are unique because of their excellent specificity and possibility to target posttranslational modifications such as phosphorylation sites, conformers or interaction regions of proteins that cannot be targeted with genetic knockout techniques and are impossible to knockdown with RNAi. The number of inhibiting cytosolic/nuclear sdAbs is increasing and usage of synthetic single pot single domain antibody libraries will boost the generation of these fascinating molecules without the need of immunization. The most frequently selected antigenic epitopes belong to viral and oncogenic proteins, followed by toxins, proteins of the nervous system as well as plant- and drosophila proteins. It is now possible to select functional sdAbs against virtually every cytosolic/ nuclear protein and desired epitope. The development of new endosomal escape protein domains and cell-penetrating peptides for efficient transfection broaden the application of inhibiting sdAbs. Last but not least, the generation of relatively new cell-specific nanoparticles such as polymersomes and polyplexes carrying cytosolic/nuclear sdAb-DNA or -protein will pave the way to apply cytosolic/ nuclear sdAbs for inhibition of viral infection and cancer in the clinic.
\end{abstract}

Keywords: intrabodies; single domain antibodies; scFv fragment; cytosolic/nuclear intrabodies; camelid VHHs; shark vNARs; human VH; human VL

Abbreviations: Nb, nanobody; NLS, nucleus leader sequence; sdAb, single domain antibody; VNAR, variable domain of the new antigen antigen receptor (IgNAR) from sharks.

${ }^{*}$ Correspondence to: Thomas Böldicke, Helmholtz Centre for Infection Research, Structure and Function of Proteins, Inhoffenstraße 7, D-38124, Braunschweig, Germany.

E-mail: thomas.boeldicke@helmholtz-hzi.de

\section{Introduction}

New insights into the function of proteins can be obtained with nucleotide-based knockout and knockdown methods at the DNA or mRNA level respectively. Knockdown and knockout methods are essential to analyze the function of proteins.

Knockdown of proteins complement these methods and is essential if post-translational modifications, 


\section{ScFvs and sdAbs targeted to subcellular compartments}
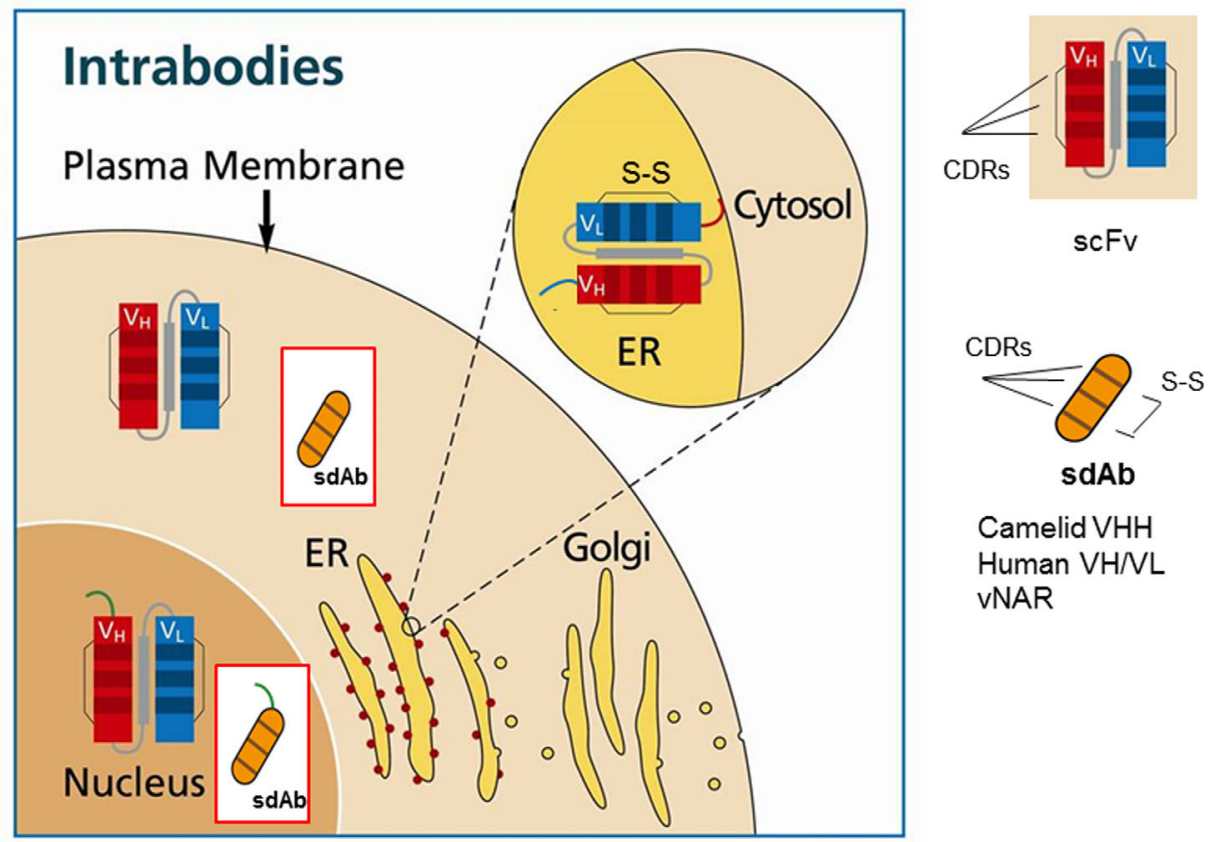

Camelid VHH Human VH/VL VNAR

Figure 1. ScFvs and sdAbs targeted to subcellular compartments. Intrabodies can be targeted to the ER, mainly as scFv fragment, where they are retained by the KDEL sequence (red line). Binding of the specific antigen will lead to retention of the antigen-ER-intrabody complex inside the ER (not shown). Alternatively, scFvs or sdAbs can be targeted to the nucleus or cytosol via a nucleus leader peptide (green line) or without leader sequence, respectively. Complementarity-determing regions are shown by lines. sdAbs from shark have only CDR1 and CDR3.

conformations and interaction regions of proteins have to be studied. Regarding knockdown at the mRNA level this cannot be achieved with siRNA technology. Today, protein inhibitors are dominant negative mutants, small molecule inhibitors including peptides, allosteric modulators, short single-stranded DNA or RNA oligonucleotides (aptamers, intramers), neutralizing antibodies and intrabodies and nonimmunoglobulin binder scaffolds such as cysteine-knot proteins, adnectins, anticalins, affibodies, and DARPins. ${ }^{1,2}$

Another class of promising knockdown molecules recently gaining importance are intracellular antibodies (intrabodies), i.e. antibodies that are expressed within the target cell that contains the corresponding antigen. Intrabodies are recombinant antibody fragments and the main advantages are their high specificity such that post-translational modifications, interaction regions, conformers, splice variants and isoforms can be targeted without off target effects. Long lasting functional inhibition of intracellular proteins can be achieved, which is not possible with classical neutralizing antibodies. Intrabodies can be specifically transported to the cytosol, nucleus or ER to bind their antigens at specific loci only (Fig. 1).

The development of cytosolic/nuclear intrabodies was hampered by the fact that intrabodies in the
scFv and Fab format cannot form disulfide bridges within the reducing environment of the cytosol and are therefore unstable. ${ }^{3,4}$

Specific strategies were developed such as the yeast two-hybrid system ${ }^{5}$ to express functional cytosolic/nuclear $\mathrm{scFv}$ intrabodies and usage of these methods led to some remarkable functional cytosolic/ nuclear scFv intrabodies. ${ }^{6}$ A breakthrough in antibody engineering was the discovery of stable expressed cytosolic/nuclear sdAbs derived from camel or shark antibodies comprising only the variable domain of the heavy chain. The variable domain of camelid heavy chain antibodies is called $\mathrm{VHH}$, the variable domain of the new antigen receptor (IgNAR) from sharks vNAR. Camelid VHHs recognizing their antigens are called nanobodies.

Both single domain antibodies derived from camels or sharks constitute intact functional antigen-binding sites, the single domain $\mathrm{VHH}$ domain with 3 complementarity determining CDR regions $^{7}$ and the vNAR domain with CDR1, CDR3 and HV2 and HV4. ${ }^{8-10}$ Camelid and shark single domain antibodies possess good solubility, high thermal stability and refolding capability. ${ }^{7,10,11}$ In addition, stable human VH and VL domains can be constructed from human antibodies after framework mutations and randomization of CDRs. ${ }^{12-18}$ Camelid nanobodies can be stably expressed inside the 


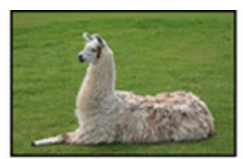

\section{Immunization of llama with target protein}

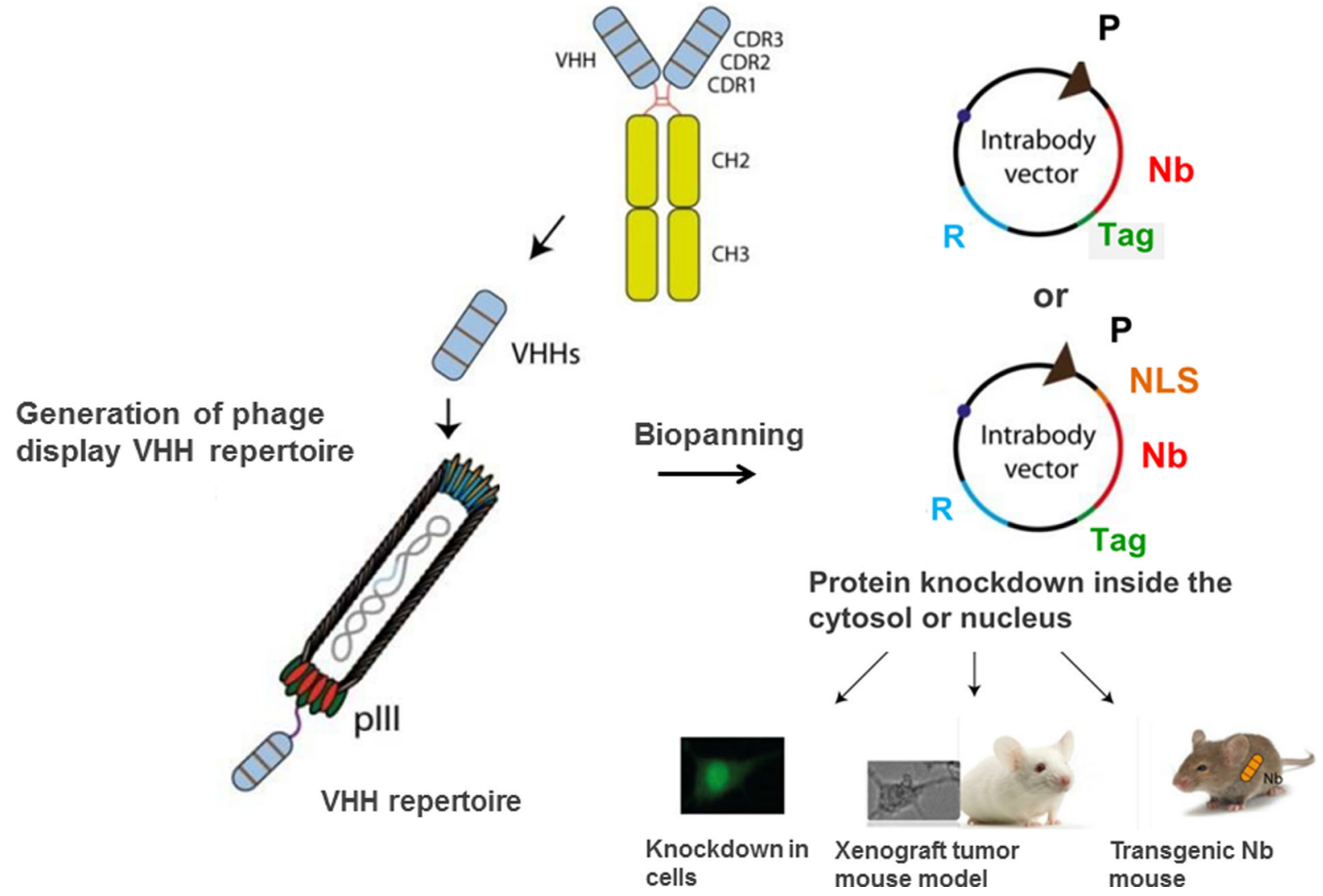

Figure 2. Construction and application of cytosolic/nuclear camelid nanobodies. Until now, most cytosolic camelid nanobodies have been constructed after immunization of camels. The VHH domains will be amplified from the cDNA isolated from the peripheral blood lymphocytes of immunized camels. Then a phage display repertoire is generated to display the VHH repertoire on the surface. Biopanning with the antigen will deliver specific recombinant nanobody phages from which the genes can be cloned into an appropriate targeting vector for expression in the cytosol or nucleus. The function of the intrabody can be tested in cell culture or applied in a xenograft tumor mouse model. Alternatively, a transgenic mouse expressing the nanobody can be generated. ( $P$, promoter; $\mathrm{R}$, resistant gene; $\mathrm{Nb}$, nanobody; NLS, nucleus leader sequence).

cytoplasm even if the disulfide bridge is not formed. ${ }^{2,6}$ Folded nanobodies can find their antigen and are then stabilized by binding to the antigen.

As an analytical tool camelid antibodies have been used to illuminate in vivo trafficking of target molecules, to detect conformational states and posttranslational modification of proteins. In addition, they have been employed as chaperons for crystallization in cases where unstable proteins are sensitive to degradation, unfolding or aggregation. ${ }^{19-23}$

In general nanobodies are selected from naïve, immune, synthetic camelid VHH single domain antibody repertoires ${ }^{24-27}$ whereas shark sdAbs and human VH and VL sdAbs are mainly selected from synthetic antibody libraries. ${ }^{12-1828-34}$

Antibody fragments are displayed on filamentous phages or yeast. Selected sdAbs can then be converted to cytosolic/nuclear intrabodies with a single cloning step (Figs. 2 and 3). In particular, universal synthetic nanobody libraries are very valuable because no immunization with the target antigen is needed. Low affinity binders can be affinity-maturated by introducing CDR mutations, randomization of mutational hotspots or by error prone PCR. ${ }^{35-37}$

The number of available inhibiting nanobodies against different cytosolic/nuclear proteins is increasing. So far most cytosolic/nuclear single domain intrabodies have been derived from camels, followed by some single domains $\mathrm{VH}$ and VL of human origin (Table I).

The targets comprise

- intracellular enzymes kinases: ${ }^{53,54,58,59,62,76-78,81}$

including

- oncogenic proteins ${ }^{56-60,62-65,68,69,81}$ 
stable human VH or VL germline framework

\begin{tabular}{|c|c|c|c|c|c|c|c|}
\hline \multicolumn{3}{|c|}{ CDR1 } & CDR2 & \multicolumn{3}{|c|}{ CDR3 } & \\
\hline FR1 & $x$ & FR2 & $x x x x x$ & FR3 & $\overline{x x}$ & FR4 & \\
\hline \multicolumn{3}{|c|}{ CDR1 } & CDR2 & \multicolumn{3}{|c|}{ CDR3 } & \\
\hline FR1 & & $R 2$ & $x X X X X$ & FR3 & $x X X$ & FR4 & VL \\
\hline
\end{tabular}

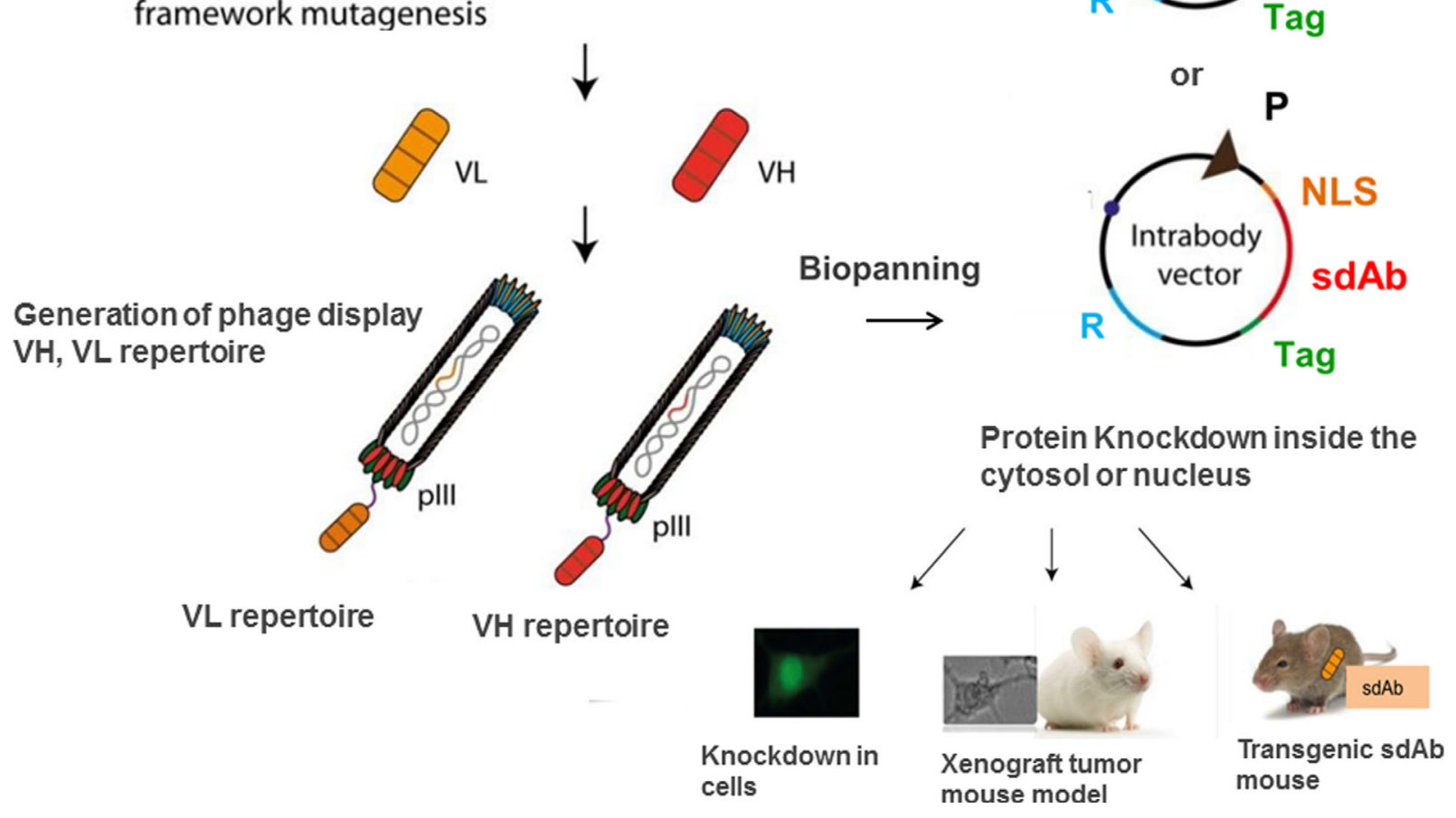

Figure 3. Construction and application of cytosolic/nuclear human VH and VL domains. Synthetic human VH/VL libraries are constructed from a stable human VH or VL germline framework or from a VH/VL scaffold of an existing antibody. After randomization of the CDRs (mainly CDR3) and possible introduction of framework mutations, human VH and VL are displayed on phages. Specific sdAbs are selected by biopanning and the sdAb-coding region is subsequently cloned into a targeting vector for expression inside the cytosol or nucleus. In vivo application follows. (P, promoter; R, resistant gene; NLS, nucleus leader sequence; sdAb, single domain antibody).

- toxins $^{53-55}$

- proteins of the nervous system ${ }^{70-73}$ and

- virus proteins ${ }^{38-52}$

- proteins from plants and drosophila ${ }^{77-80}$

Most cytosolic/nuclear sdAbs have been evaluated in living cells but in vivo application of single domain intrabodies in mice is well documented, too. ${ }^{57,60,81}$ In the future, generation of transgenic mice expressing cytosolic/nuclear sdAb is possible and very useful if a corresponding genetic knockout is lethal. ${ }^{82}$

\section{ER intrabodies versus cytosolic/nuclear intrabodies}

ER-intrabody knockdown function is based on retention of molecules passing the secretory pathway via the KDEL sequence fused to the C-terminal end of the intrabody. ${ }^{6,83-85}$ In the past ER-intrabodies have been the most promising molecules because they are correctly folded in the ER environment. ${ }^{86}$ Contrary to ER intrabodies which have only to bind to the antigen inside the ER, cytosolic/nuclear intrabodies have to inactivate their targets by binding to the antigen and inducing a conformational change or interfering with the binding of the target protein to its specific binding partner. Intrabodies targeted to the ER (ER-intrabodies) are mostly expressed as $\mathrm{scFv}$ fragment, cytosolic/nuclear intrabodies as $\mathrm{scFv}$ or recently as much more stable single domain antibody. ${ }^{6,87,88}$ Due to the high stability of sdAbs in the cytosol/nucleus compared to scFv fragments and efficient reliable selection techniques based on phage and yeast display, the knockdown of cytosolic/nuclear proteins by sdAbs is very promising.

\section{Cytosolic/nuclear intrabodies}

To select stable correctly folded scFv fragments, specific in vivo selection in eukaryotes such as yeast or in prokaryotes such as E.coli has to be performed. ${ }^{6}$ Possible options are also expression of $\mathrm{scFv}$-protein fusions and CDR grafting or introduction of 


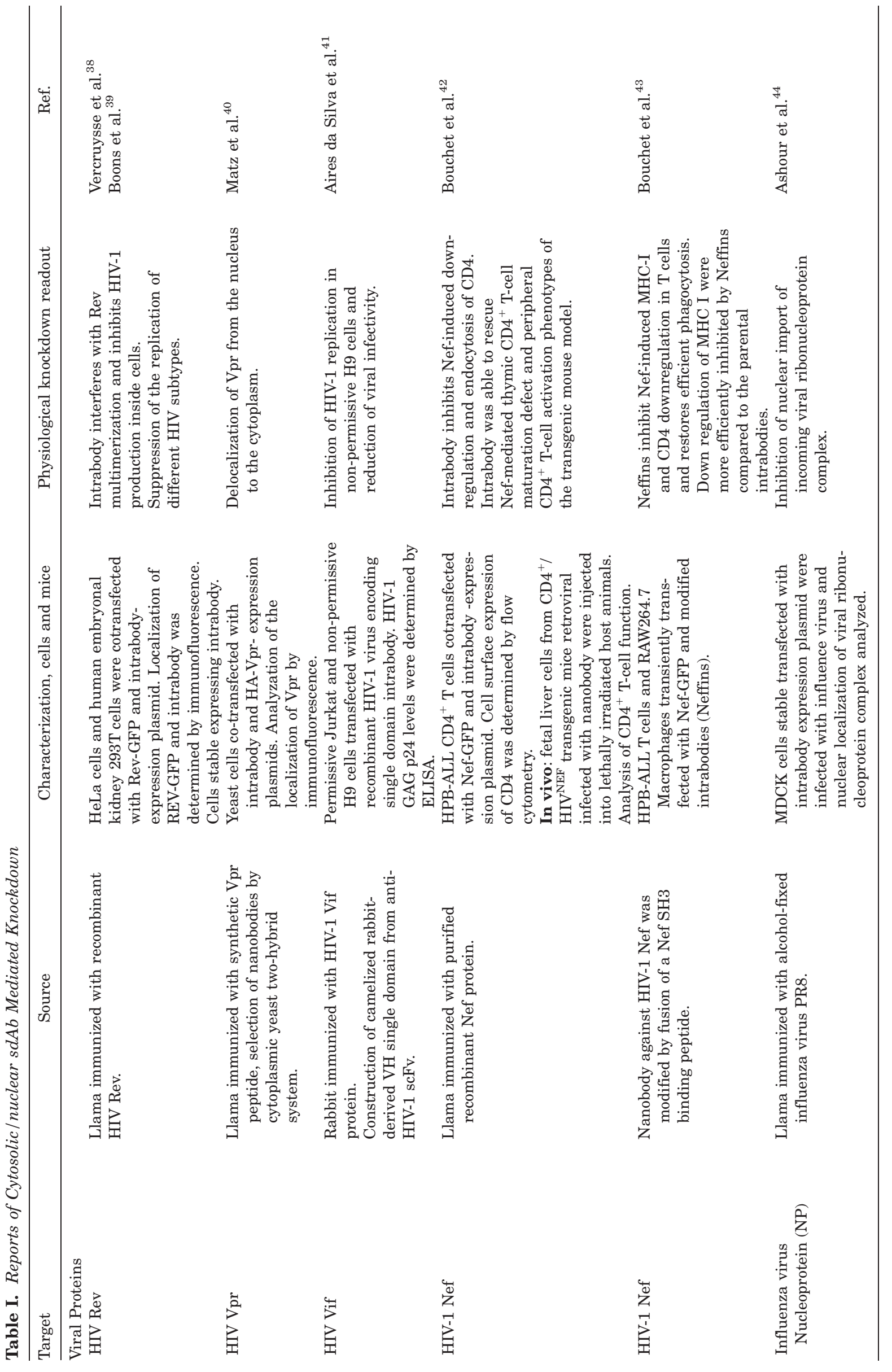




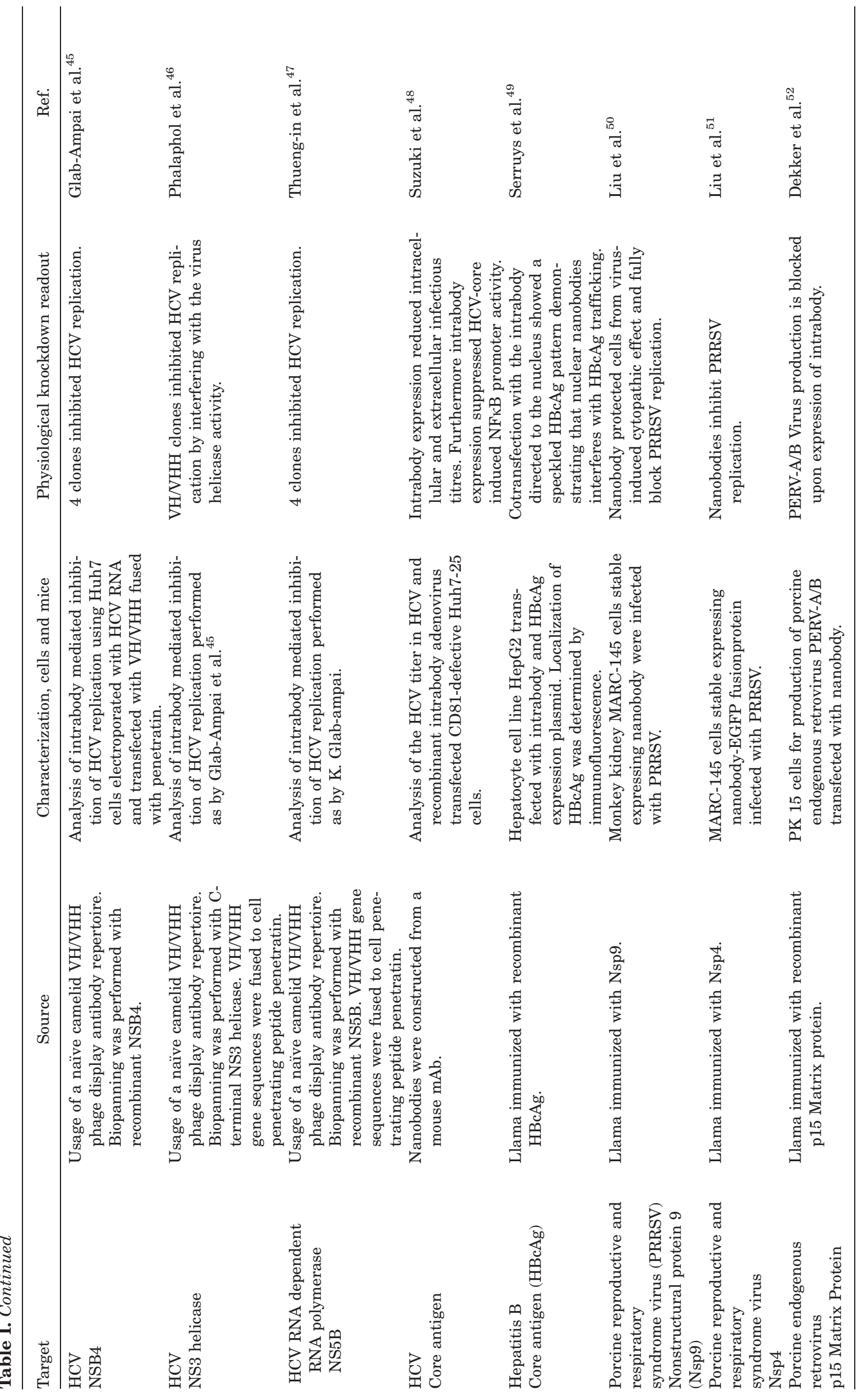




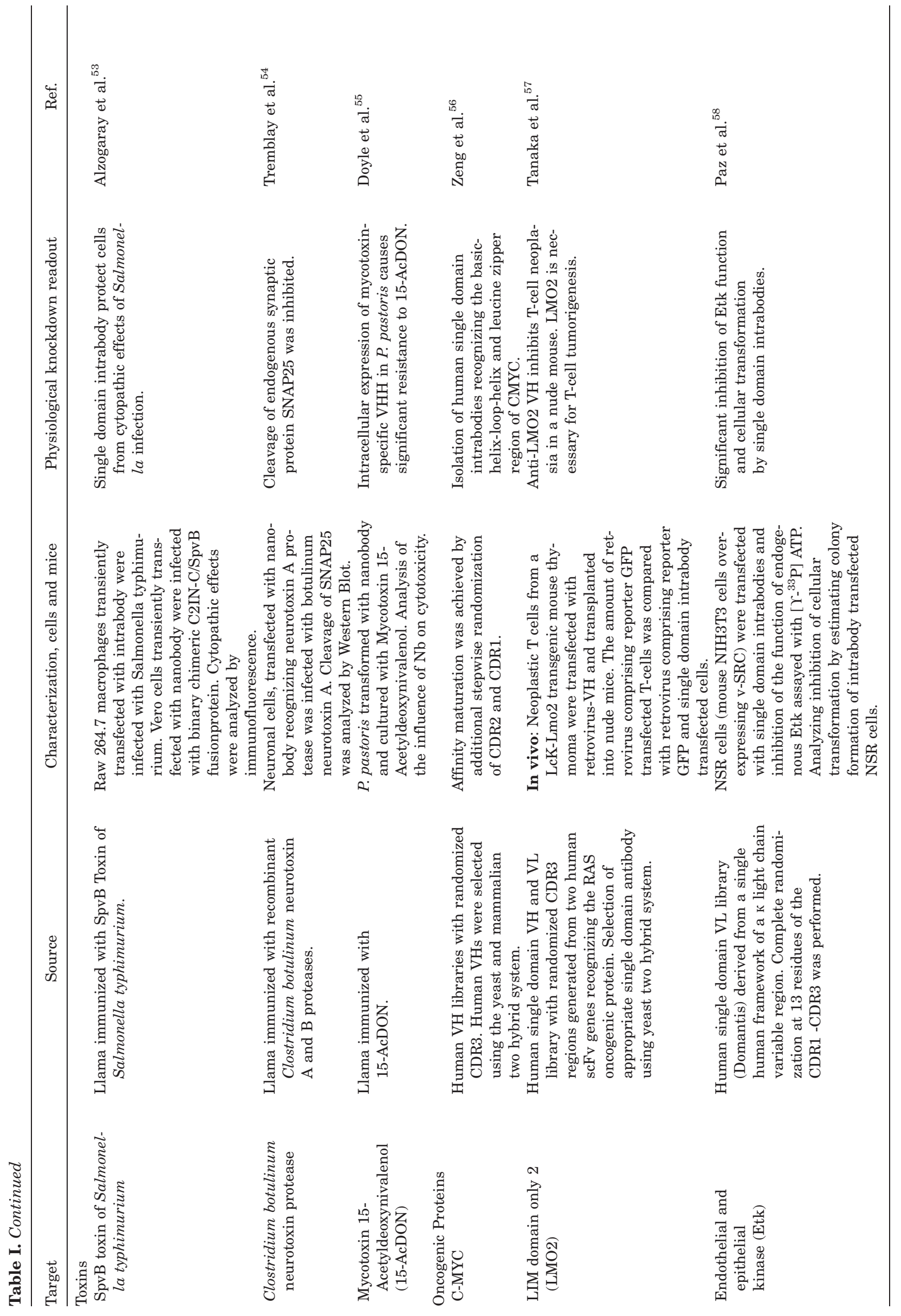




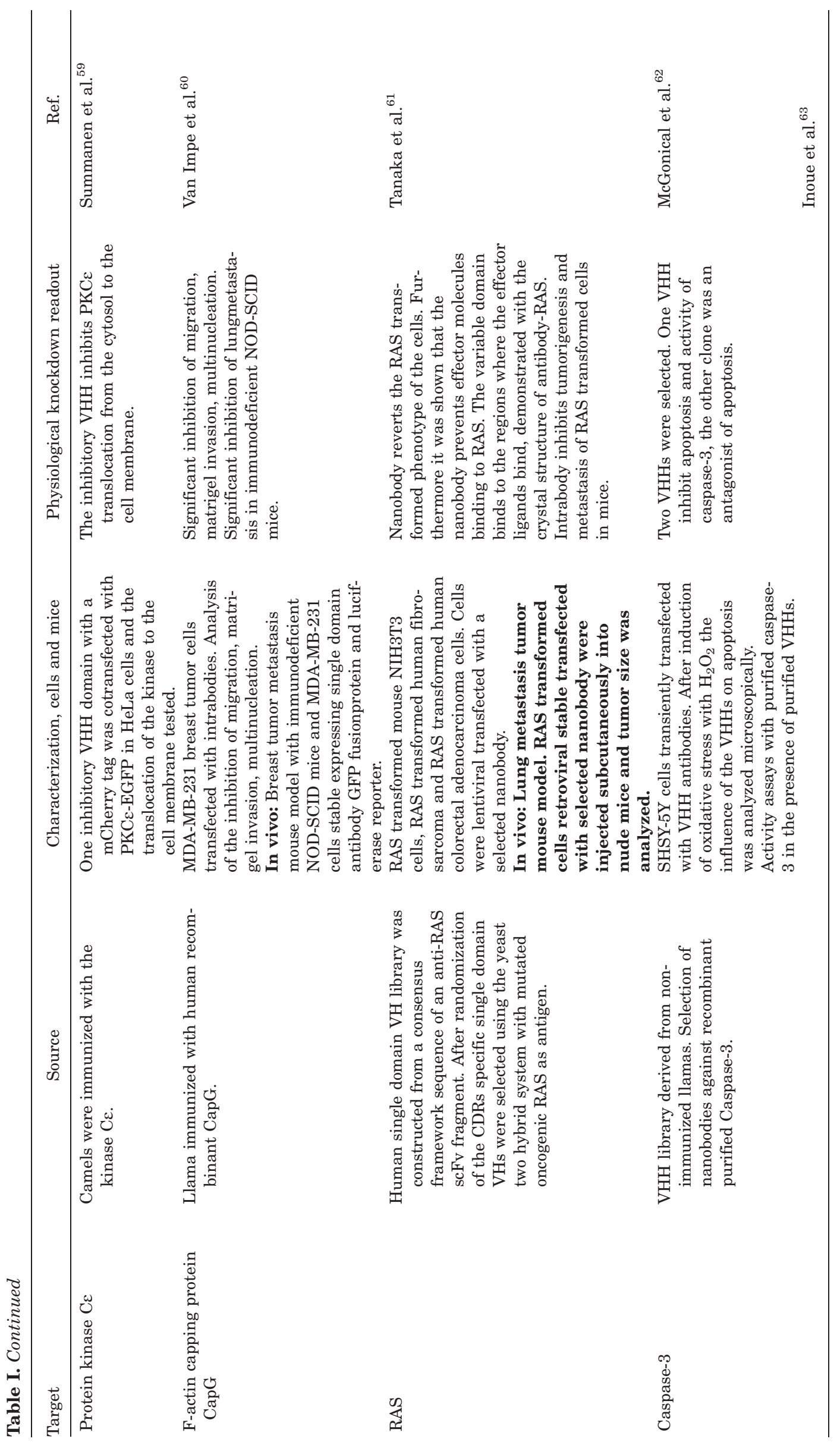




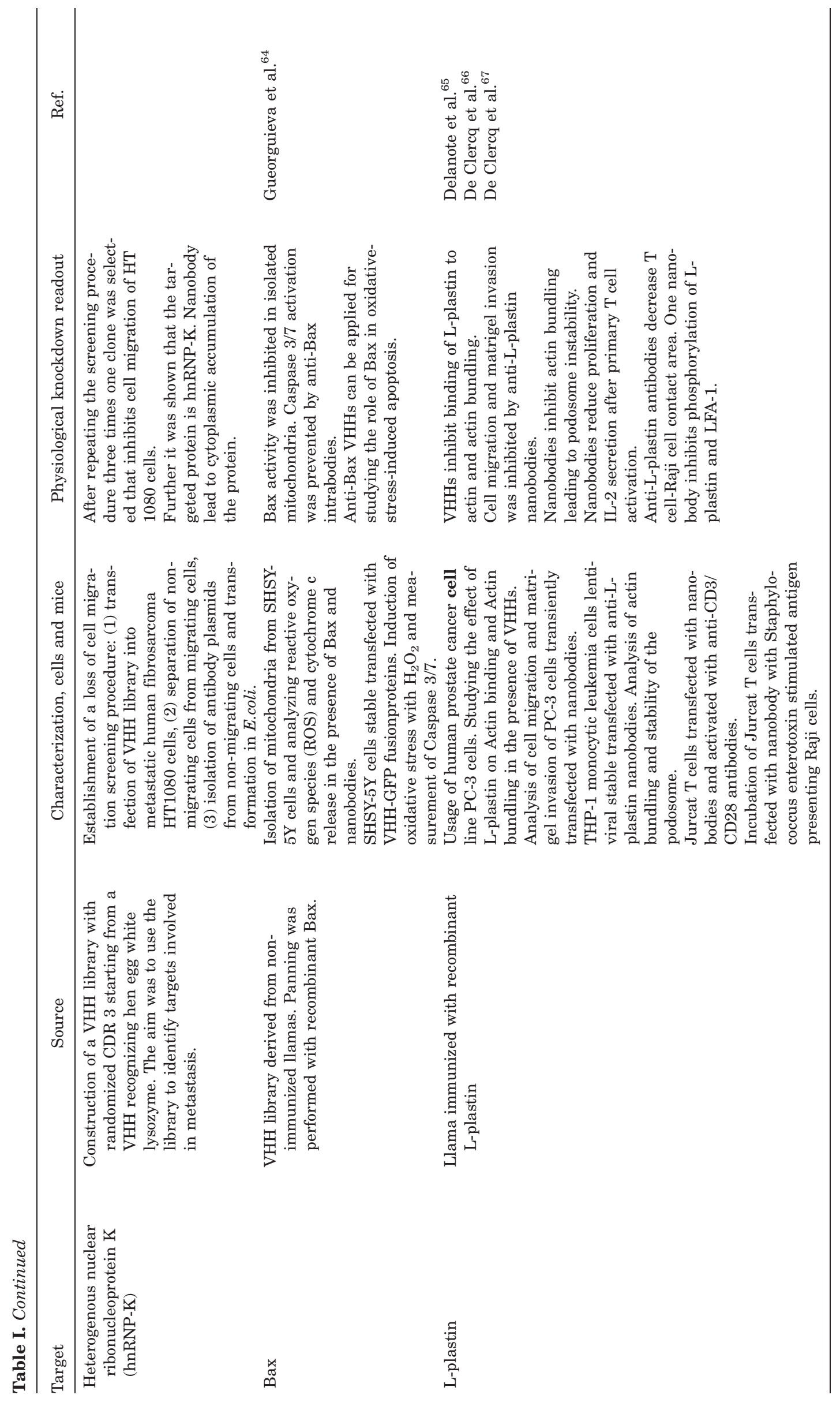




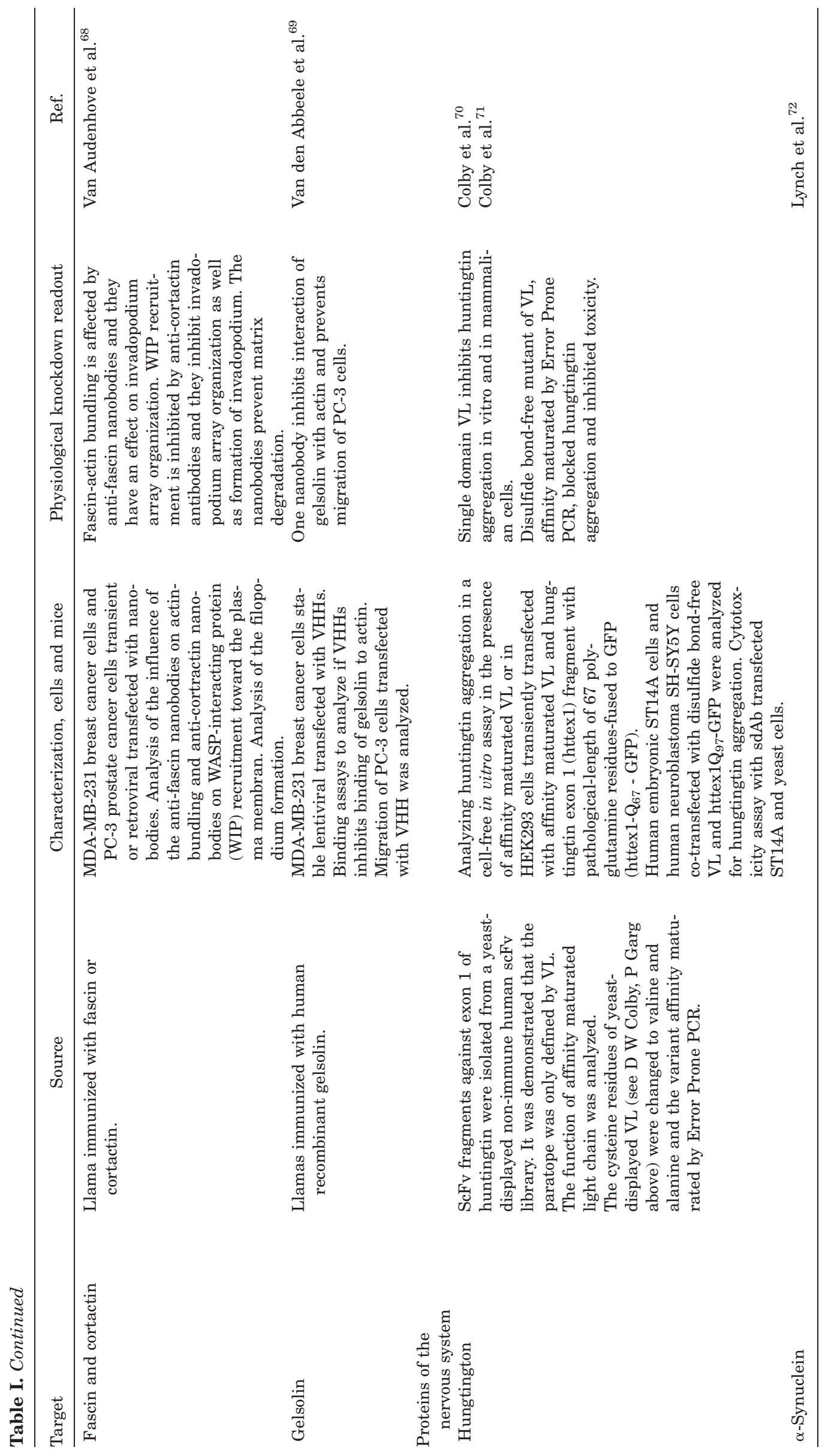




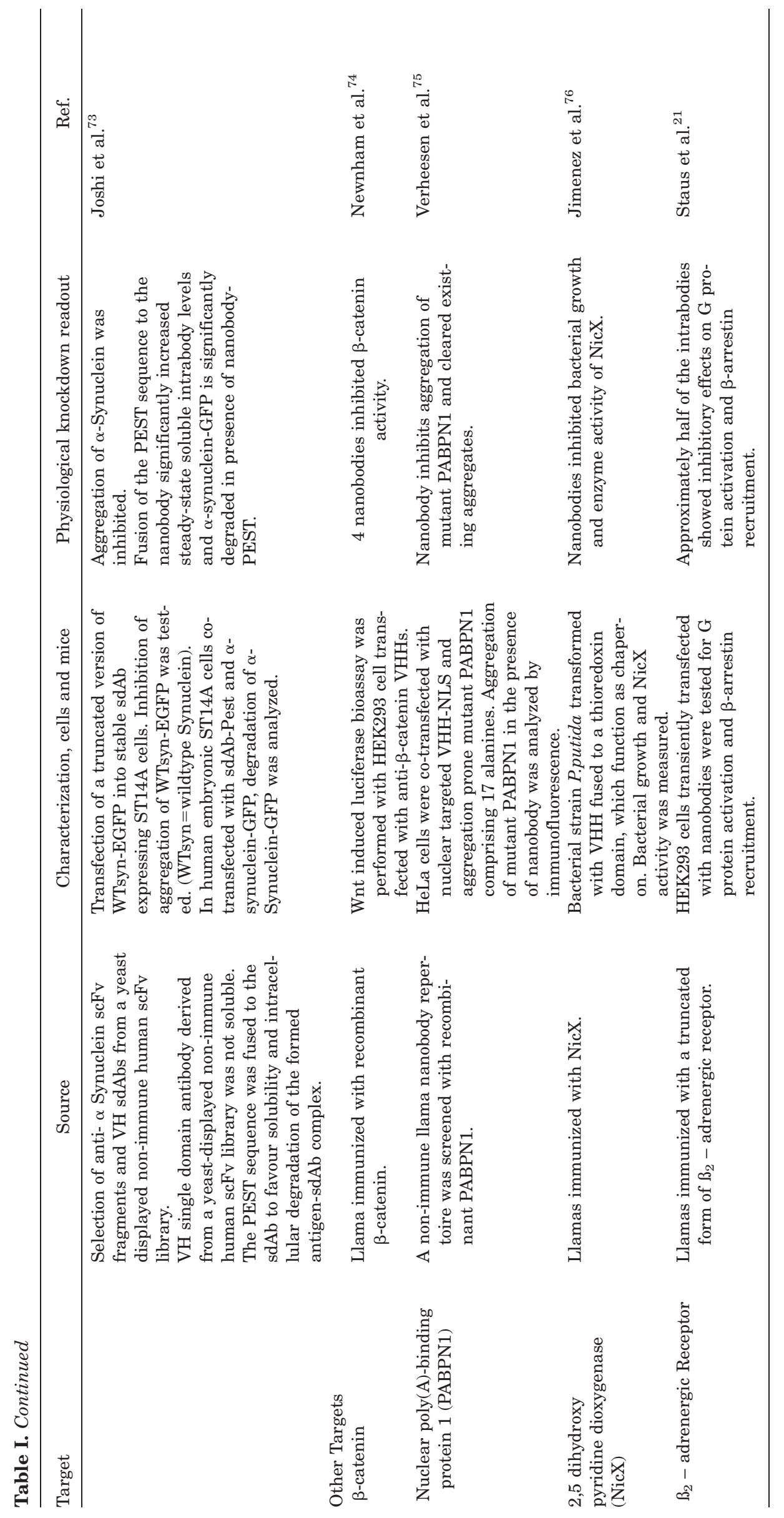




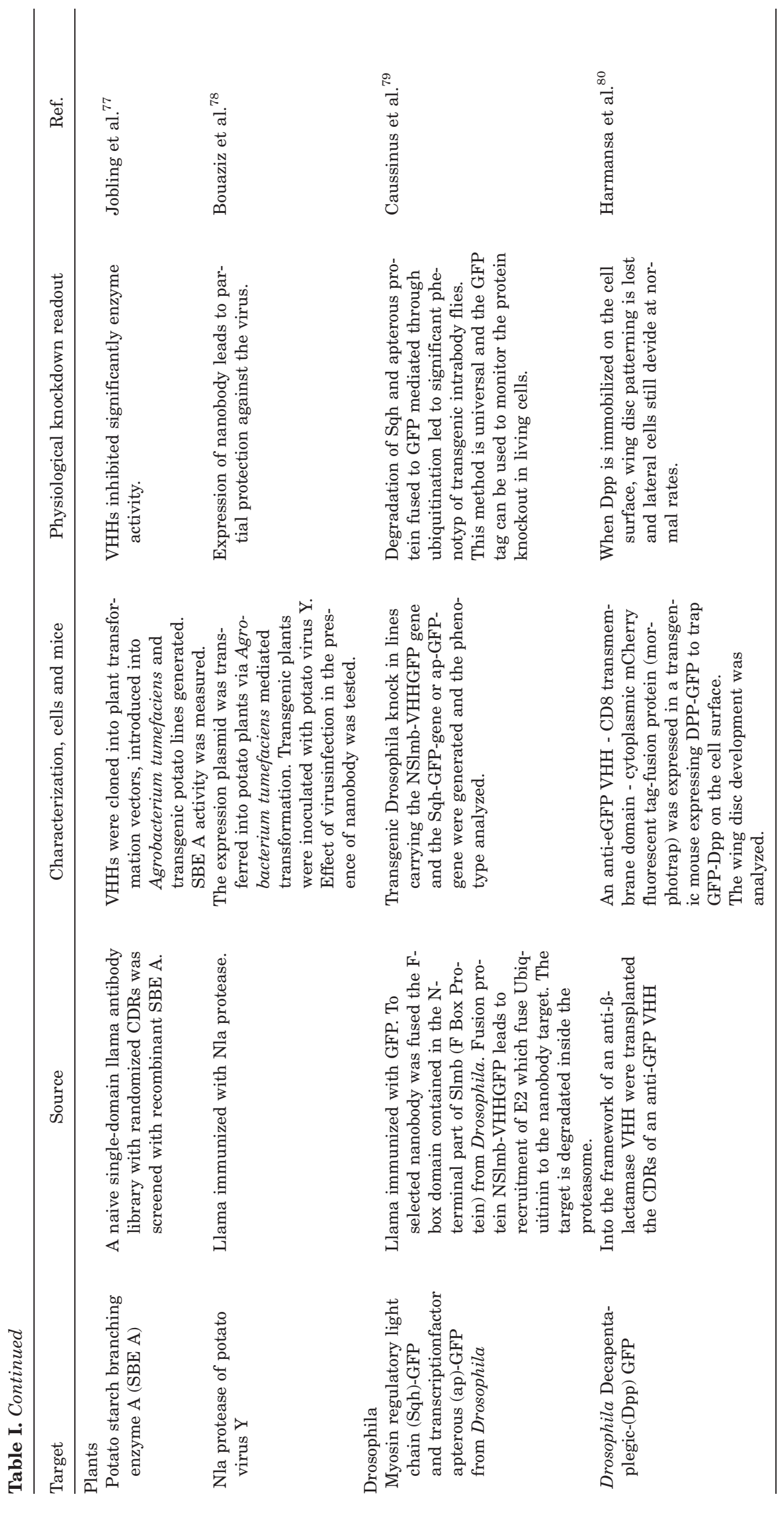


synthetic CDRs in stable frameworks. ${ }^{6}$ The most frequently used method to select functional scFv's is the Antibody Capture Technology (IACT) based on the yeast 2-hybrid system. ${ }^{5}$ The next paragraph summarizes the targets against which $\mathrm{scFv}$ fragments have been selected by IACT and describes some new scFv's inhibiting the degradation of p53 and restoring the activity of mutated p53, respectively.

\section{ScFv format}

Many different scFv's have been isolated by IACT, for example against Tau, amyloid- $\beta$ peptide, asynuclein, proNGF, gephyrin, Syk, EGFR, BCRABL, caspase 3, aggrecanase-2 and NSP5 from rotavirus. ${ }^{6}$

Recently, a scFv fragment against the E6 oncoprotein of HPV selected by IACT was targeted to the nucleus where it inhibits the ability of HPV16 E6 (16E6) to mediate p53 degradation and causes cell death of HPV16-positive cells. ${ }^{89}$ Additionally, the nucleus-targeted intrabody inhibited tumor activity of HPV16-positive tumor cells in two pre-clinical mouse models. Interestingly, two bispecific $\mathrm{scFv}$ fragments have been constructed that (1) comprises a $\mathrm{scFv}$ that targets the nucleus and a $\mathrm{scFv}$ fragment that restored the function of mutated p53 and (2) comprises the intracellular nuclear transport $\mathrm{scFv}$ fragment and a scFv fragment that binds Mdm2 and prevents destruction of p53 by $\mathrm{Mdm} 2 .{ }^{90}$ All three $\mathrm{scFv}$ fragments were constructed from corresponding hybridoma clones.

\section{Single domain format}

In contrast to the time-consuming strategies for selection of functional cytosolic/nuclear scFv's, nanobodies can be directly selected from immune, naïve or synthetic libraries displayed on phage or yeast which significantly shortens the isolation of binders. Single domain antibodies are composed of only one $\mathrm{V}$ region (variable domain of the heavy or light chain) and in numerous examples it was shown that sdAbs can be stably expressed inside the cytoplasm or nucleus (Table I). In the next paragraph, current methods for construction and selection of camelid, shark and human sdAbs including new developments will be summarized.

\section{Generation of cytosolic/nuclear single domain intrabodies}

Single domains antibodies can be generated from camelid heavy-chain IgGs (VHHs), from cartilaginous fish IgNARs $\left(\mathrm{V}_{\mathrm{NAR}}^{\mathrm{s}}\right)$ or from conventional human IgGs (VH and VL). The antibody repertoires can be derived after immunization of camels or sharks, build up from naïve natural antibody sequences or synthetically constructed based on stable scaffolds. ${ }^{10,24,56-58,61,63,81}$ However, the process of immunization of sharks is demanding in comparison to immunization of mammals. Therefore, shark nanobodies have mostly been selected from synthetic repertoires. Human single domain $\mathrm{VH}$ and $\mathrm{VL}$ domains were selected from synthetic human $\mathrm{VH}$ or VL antibody repertoires.

\section{Strategies to Construct Camelid VHH Repertoires}

\section{Construction of immune camelid VHH libraries}

Camelid VHHs repertoires for the selection of single domain antibodies are mostly generated after immunization of camels. PCR amplification of VHH can be performed with primers binding to the $\mathrm{N}$-terminus and $\mathrm{CH} 2$ region of camel heavy chain IgG cDNA, followed by nested PCR amplifying the VHH coding region. The product is cloned into a phagemid vector and a phage antibody repertoire established ${ }^{91}$ (Fig. 2).

\section{Examples of cytosolic/nuclear nanobodies from immune camelid $\mathbf{V H H}$ libraries}

So far, most nanobodies and cytosolic/nuclear nanobodies have been selected after immunization of llamas with the target protein. Nanobodies inhibited the function of HIV Rev, ${ }^{38,39} \mathrm{HIV} \mathrm{Vpr}^{40}$ HIV-1 Nef, ${ }^{42,43}$ influenza virus nucleoprotein, ${ }^{44}$ hepatitis B Core antigen $(\mathrm{HBcAg}){ }^{49}$ nonstructural proteins 9 and 4 of porcine reproductive and respiratory syndrome virus (PRRSV), ${ }^{50,51}$ p15 matrix protein of porcine endogenous retrovirus, ${ }^{52} \mathrm{SpvB}$ toxin of Salmonella typhimurium, ${ }^{53}$ neurotoxine protease of Clostridium botulinum, ${ }^{54}$ mycotoxin 15-Acetyldeoxynivalenol (15AcDON) ${ }^{55}$ protein kinase $\mathrm{C} \varepsilon,{ }^{59} \mathrm{~F}$-actin capping protein CapG, ${ }^{60}$ L-plastin, ${ }^{65}$ fascin and cortactin, ${ }^{68}$ gelsolin, ${ }^{69} \beta$-catenin, ${ }^{74} 2.5$ dihydroxy pyridine dioxygenase (NicX), ${ }^{76} \beta_{2}$-adrenergic receptor, ${ }^{21} \mathrm{Nla}$ protease of potato virus $\mathrm{Y}^{78}$ and GFP for depletion of target GFP-fusions in eukaryotics. ${ }^{79}$

Naïve and synthetic single domains libraries have the advantage that no immunization of animals is needed. A disadvantage is that the selected sdAbs are not affinity maturated. Nevertheless, if these libraries contain a high number of clones with high diversity, sdAbs against all possible targets and epitops should be identifyable. Selected sdAbs can then easily be converted into cytosolic/nuclear antibody fragments by one cloning step (Fig. 3). In the next paragraphs, the principles of the generation of naïve and synthetic libraries together with some new developments are shown.

\section{Construction of naïve camelid VHH libraries}

Naïve llama VHH libraries are single pot or universal libraries generated from blood samples from several animals for the selection of a large number of different specificities. ${ }^{92}$ Naïve libraries with different 
sizes have been constructed ranging from $10^{7}$ to 5 $\times 10^{9}$ clones. $^{25,93}$ Recently, ribosome display with nanobodies has been performed with an expression cassette that can easily be used for in vitro synthesis of ribosome-VHH complexes in different expression systems. $^{94}$

\section{Examples of cytosolic/nuclear naive VHHs}

Some interesting naïve cytosolic/nuclear nanobodies have been generated particularly against nonstructural membrane protein NSB4 of $\mathrm{HCV},{ }^{45} \mathrm{Bax},{ }^{64}$ NS3 helicase of $\mathrm{HCV}^{46}$ RNA dependent RNA polymerase NS5B, ${ }^{47}$ nuclear poly(A)-binding protein 1 $(\mathrm{PABPN} 1)^{75}$ and Caspase-3. ${ }^{62}$

\section{Construction of synthetic VHH libraries}

Synthetic camelid VHH libraries have been constructed based on natural VHH frameworks. Antigen binding diversity has been introduced by randomization of the CDRs, mainly CDR3. ${ }^{95}$ Interestingly, a semi-synthetic library has been constructed from 3 unimmunized llamas. In this case, the CDRs and frameworks were diversified by errorprone PCR and then these sequences were spliced together through the common framework overlaps by PCR. ${ }^{96,97}$

\section{Examples of synthetic cytosolic/nuclear nanobodies}

A specific nanobody that leads to cytoplasmic accumulation of heterogenous nuclear ribonucleoprotein $\mathrm{K}$ (hnRPN-K) has been selected. ${ }^{63}$ Furthermore, a nanobody that significantly inhibits the enzyme activity of potato starch branching enzyme has been generated. ${ }^{77}$ Recently, a very stable variant of an anti-GFP nanobody was constructed by transplantation of the CDRs from an anti-GFP VHH to a stable framework of an anti- $\beta$ lactamase $\mathrm{VHH}{ }^{98}$ This antibody was part of the morphotrap that was used to analyze the function of Drosophila Decapentaplegic (Dpp) on wing disc development. ${ }^{80}$

\section{Non camelid sdAb libraries}

Construction of synthetic human VH/VL libraries Synthetic human VH/VL libraries are constructed from a stable human VH/VL germline framework or from a VH/VL scaffold of a human monoclonal antibody. Randomization of the CDRs, especially of CDR3, leads to synthetic human VH libraries with high diversity. ${ }^{6,12-16,99}$ VL single domain antibody libraries have been constructed similarly ${ }^{16-18}$ (Fig. 3 ). Recently a synthetic library was constructed comprising the Ig1 domain of human neural cell adhesion molecule 1 (NCAM) in which randomized CDR1 and CDR3 from a shark clone were transplanted. ${ }^{100}$ Chimeric antibodies were selected that block the signaling activity of chemokine receptor CXCR4.
Examples of synthetic human VH/VL cytosolic/ nuclear sdAbs. Anti-myc human VH single domain antibodies have been selected from a synthetic human VH library based on a VH consensus framework of an anti-RAS scFv. Stepwise randomization of CDR3, CDR2 and CDR1 followed by yeast two hybrid system selection led to specific anti-cmyc clones. ${ }^{56,61}$ Similarly, an anti-RAS human VH and anti-LIM domain only 2 (LMO2) VH domain was selected. ${ }^{57,81}$ The anti-RAS VH inhibited RASdependent tumorigenesis in a mouse tumor model and the anti-LM02 antibody fragment inhibits T-cell neoplasia in a nude mouse. An anti-epithelial kinase (Etk) human VL was selected from a synthetic library based on a human $\kappa$ domain framework with randomized CDR3s. ${ }^{58}$

Furthermore, camelization of human $\mathrm{VHs}$ can be performed by introduction of point mutations in the $\mathrm{VH}$ framework of an human antibody, mainly framework 2 to render the overall structure more hydrophilic. ${ }^{88}$ Such camelized human VH frameworks have been used to generate CDR3 randomized single domain antibody repertoires displayed on phages for selection of new binders with improved solubility and refolding efficiency. ${ }^{101,102}$ Interestingly a rabbit-derived anti-HIV Vif VH single-domain intrabody was active in its camelized format. ${ }^{41}$

\section{Construction of synthetic IgNAR variable domain (vNAR) libraries}

In general, vNAR libraries have been selected from semi-synthetic libraries based on naturally occurring vNAR sequences and randomized CDR 3 loops. ${ }^{28-32}$ A shark anti-hen egg-white lysozyme IgNAR VH clone was used as the scaffold for the generation of a semi-synthetic library with randomized CDR 3 loops. ${ }^{33}$ Interestingly, a neutralizing VNAR singledomain antibody against BAFF that blocked the binding of BAFF to all three of its receptors was selected recently. In this case, the shark antibody repertoire was based on Type 2 nurse shark VNAR frameworks with a number of framework mutations and partial randomization of CDR3. ${ }^{34}$ At present, no shark cytosolic/nuclear sdAb have been reported in the literature.

\section{Selection of cytosolic/nuclear sdAbs}

For selection of antigen-specific sdAbs, the sdAb repertoires are displayed on phages or on the cell surface of yeast cells. Then, by incubation of the recombinant phage antibody repertoire with immobilized antigen (biopanning), specific binders will be selected and cloned into a cytosolic or nuclear targeting vector (Figs. 2 and 3). The cytosolic or nuclear intrabodies will be evaluated in target cells, in xenograft tumor mouse models or transgenic $\mathrm{sdAb}$ mice. 
Recently, a promising screening method to identify functional sdAbs has been developed. ${ }^{103}$ Alpacas were immunized with a mixture of inactivated influenza A virus (IAV) and vesicular stomatitis virus (VSV). Generated VHH cDNAs were subsequently directly cloned into a retroviral vector to produce lentivirus particles. Then, A549 cells were infected with recombinant viruses and after $48 \mathrm{~h}$ treated with a lethal dosis of IAV and VSV. Surviving colonies were further characterized and the sequences of the VHHs were determined. After this screen, 19 VHHs that specifically block infection of cells with IAV or VSV were isolated. This screening approach should be applicable to identify inhibitors of any pathogen or biological pathway.

Most sdAbs have been selected by phage display without additional usage of the bacterial-, yeast- or mammalian-two hybrid system. This approach is usually reliable and can be used for selection of cytosolic/nuclear scFv fragments as well as sdAbs because cytosolic/nuclear selection will favor wellfolded $\mathrm{scFv}$ fragments or sdAbs rather than the high affinity ones. However, it is still unclear if the affinity of antibodies is the only prerequisite for efficient intrabody engineering. Usage of bacterial-, yeast- or mammalian-two hybrid systems enables direct in vivo selection of functional cytosolic/nuclear intrabodies without the need of purified antigen. ${ }^{104-106}$ Another two-hybrid assay that allows studying the interaction of two proteins in living cells directly has been developed. ${ }^{107}$ Here, a fluorescently labeled prey protein and the corresponding bait protein fused to fluorescently labeled lacI are coexpressed in mammalian cells that contain chromosomally integrated lac operator. Interaction of both molecules results in co-localization of two different fluorescent signals at the lac operator, which can be observed as a spot within the nucleus. The next paragraph provides a list of the selection and description of all known cytosolic/nuclear sdAbs derived from camels and human antibodies. Cytosolic sdAbs are descripted which have been successfully applied in xenograft tumor models and in addition a nanobody-GFP fusion protein is highlighted which is universally applicable for monitoring protein knockout in living cells.

\section{Examples of cytosolic/nuclear single domain antibodies}

Cytosolic/nuclear nanobodies that interfere with the function of approximately 40 cytosolic/nuclear targets have been generated successfully (Table I: reports of cytosolic/nuclear sdAb mediated knockdown). Compared to this number of cytosolic/nuclear targets ER-intrabodies against approximately 35 transitory proteins have been reported. Most sdAbtargets belong to viral or oncogenic proteins, followed by toxins and proteins of the nervous system.
Cytosolic intrabodies have also successfully been expressed in plants and in Drosophila. Single domain intrabodies partially protected potato plants against potato virus $\mathrm{Y}^{78} \mathrm{~A}$ universal method has been developed to monitor protein knockout in living cells. ${ }^{79}$ To achieve this anti-GFP VHHs were fused to an F-box domain of Drosophila Slmb for degradation of targets fused to GFP via the ubiquitin depletion pathway. The technique was applied for the degradation of a transcription factor and a protein involved in morphogenesis of transgenic Drosophila monogaster flies expressing GFP-target protein and anti-GFP VHH. In addition an anti-eGFP - CD8 transmembrane domain - cytoplasmic mCherryfusion protein (morphotrap) was developed to study wing disc development in transgenic flies expressing eGFP-morphogenetic protein Decapentaplegic (Dpp) and the morphotrap. The morphotrap immobilized eGFP-Dpp on the cell surface, leading to inhibition of wing disc patterning. ${ }^{80}$ Even gene silencing using sequence-selective and nucleic-acid hydrolyzing nanobodies is now possible. ${ }^{108}$

Most sdAbs have been tested in cell culture and only few have been investigated in mice as an animal model. SdAbs against LIM domain only 2 (LMO2), F-Actin capping protein CapG and RAS were tested in appropriate xenograft tumor mouse models by transplanting tumor cells expressing the corresponding intrabody in nude mice or NOD-SCID mice. ${ }^{57,60,81}$ In addition an anti-HIV-1 Nef intrabody was able to rescue Nef-mediated thymic CD4 ${ }^{+}$T-cell maturation defect and peripheral $\mathrm{CD} 4^{+}$T-cell activation phenotypes in $\mathrm{CD} 4^{+} / \mathrm{HIV}^{\mathrm{NEF}}$ transgenic mice. ${ }^{42}$ Interestingly, fusion of a loop of a SH3 domain to one selected nanobody improved some inhibiting HIV-1 Nef functions. ${ }^{43}$ Furthermore a cysteine-free human VL has been selected ${ }^{71}$ with better activity as the original antibody fragment. Interestingly changing the cysteine residues to valine and alanine led to lower affinity as the original antibody domain with the cysteins. An improved cysteine-free variant could be selected after random mutagenesis using error-prone PCR.

Several nanobodies against viral proteins, toxins, oncogenic proteins and proteins of the nervous system have therapeutic potential (table: reports of cytosolic/nuclear sdAb mediated knockdown). In the next paragraph new developments in protein delivery of $\mathrm{scFv}$ fragments/sdAbs and model proteins into the cytosol/nucleus of target cells will be shown.

\section{Protein transfection with cytosolic/nuclear sdAbs}

Alternatively to viral transfection or plasmid transfection, intrabodies can be delivered as proteins into the cytosol (profection). Delivery of intrabodies in the $\mathrm{scFv}$ or nanobody format into the cytosol of a target cell has the advantage that the intrabodies 
retain their disulfide bridges for correct folding. Further, this method might be a safe alternative to viral gene transfer for clinical approaches.

The delivery of antibodies to the cytosol using different profection reagents has been studied in detail and was compared to electroporation, which was found to be the most effective reliable technique. ${ }^{109}$

Alternatively, fusion of cell penetrating peptides or targeting proteins (ligands or antibodies) together with translocation domains or usage of cell penetrating peptides fused to endosome escape domains has been investigated. ${ }^{109,110}$ Fusion of peptides and proteins to reach the cytoplasm is often not very efficient because of inefficient endosomal escape. ${ }^{110}$ However, a cell penetrating anti-DNA antibody localizes to the nucleus through a nucleoside salvage pathway and is used as a delivery vehicle and combined with specific targeting scFvs. ${ }^{90}$

Some highlights referring to cell-penetrating peptides should be mentioned. Highly efficient delivery was achieved using a cell-penetrating peptideadaptor system built of TAT-calmodulin fusion and a fusion consisting of calmodulin binding site and cargo. ${ }^{111}$ TAT-calmodulin non-covalently binds, delivers and releases cargo into the cytoplasm. Another system uses cell-penetrating peptides binding to heparan sulfate glycosaminoglycan fused to a protein transduction domain. Cell types that are generally difficult to transduce, such as mouse embryonic stem cells (mESCs), human ESCs and human induced pluripotent stem cells (hiPSCs), have been efficiently transfected. ${ }^{112}$ Furthermore, camelid nanobodies against HCV proteins have been fused to cell penetrating penetrin and were successfully applied in HVC infected cells. ${ }^{45-47,113}$

It was shown that the osteoblast transcription factor Runx 2 can be targeted to the nucleus of mesenchymal cells by the peptide dentin phosphophoryn, bypassing the lysosomal degradation pathway. ${ }^{114}$ Recently, an efficient serum-stable and low-toxic molecular transporter comprising one rigid planar core and four flexible arms with one guanidinium group on each arm was constructed to efficiently deliver small cargoes and large active proteins into cytosol. ${ }^{115}$ A very interesting approach combined the TAT cell penetrating peptide to an endosomal escape sequence and GFPß11 peptide. Endosomal escape can be measured by binding of GFPß11 to non-fluorescent GFP $\beta 1-10$, inducing chemical formation of the GFP fluorescent chromophore. The assay enables screening of the next generation of endosomal escape domains. ${ }^{116}$

In addition, highly efficient cyclic cell-penetrating peptides have been designed. These cyclic peptides are characterized by efficient release from the endosome. ${ }^{117}$ Last but not least, the solvent exposed residues of the framework region of nanobodies have been mutated to positively charged arginines or lysines (cationic resurfacing), leading to cell penetration. ${ }^{118}$ This approach has the potential to build a general applicable scaffold to transport nanobodies into the cell.

A very promising additional approach is the usage of the type VI secretion pathway of pathogenic bacteria to transport sdAbs into human cells. ${ }^{119}$ The injection of the sdAbs does not require bacterial invasion or the transfer of genetic material.

The approach to deliver drugs or toxins specifically to tumors mediated by nanoparticles decorated with nanobodies has been demonstrated in many in vitro examples and is now beginning to be tested in vivo. ${ }^{88}$ Polymersomes and polyplexes are relatively new artificial vesicles that can be modified simply by modifying the polymer-building blocks. ${ }^{120,121}$ It might be very attractive to encapsule recombinant cytosolic sdAb or sdAb expression plasmids into nanoparticles decorated with an specific antireceptor nanobody (for example $\mathrm{EGFR}^{122}$ to deliver cytosolic anti-cancer single domain antibodies to tumor cells. Furthermore, nanoparticles/nanotubes coated with transferrin or Angiopep-2, a ligand for the low-density lipoprotein receptor-related protein-1 (LRP1), demonstrated translocation across the blood-brain barrier. ${ }^{123,124}$ The delivery of cytosolic/ nuclear single domain intrabodies into the brain (for example recognizing hungtington protein or $\alpha$-Synuclein $)^{71,72}$ might be possible in the future.

\section{Conclusion}

Single domain antibodies from camels, shark and humans are very useful to efficiently and specifically knock down cytosolic and nuclear proteins in vivo.

The option to specifically target interaction regions, conformers, splice variants, isoforms and even posttranslational modifications such as phosphorylation sites ${ }^{21,22,34,58,125-127}$ makes intrabodies very unique and valuable. RNAi, on the other hand, has the disadvantage of demonstrating off-target effects $^{128,129}$ even if allele specific inhibition of Hungtington protein and inactivation of oncogenic mutations of p53 by RNAi have been reported. ${ }^{130,131}$

The availability of synthetic universal, single-pot camelid, shark and human single domain antibody libraries displayed on phages or yeast cells enables selection of a huge number of different single domain intrabodies theoretically directed against any antigen and desired epitope. ${ }^{12-18,28-31,33,34,95,96,132}$ By using antibody affinity maturation strategies, binders with high affinity can be isolated from these nonaffinitymaturated universal libraries by introducing CDR mutations, randomization of mutational hotspots or error prone PCR. ${ }^{35-37}$ Usage of a recently published method based on selection of specific inhibitory dAbs by recombinant lentiviruses to omit phage display selection will be attractive in the future. ${ }^{103}$ 
Strategies to apply cytosolic/nuclear single domain intrabodies in the clinic may become possible with cell penetrating peptides, ${ }^{45-47,113}$ new optimized endosomal escape domains, ${ }^{116} \mathrm{sdAb}$ expression plasmids or recombinant sdAbs embedded into nanoparticles such as polymersomes and polyplexes. ${ }^{88}$ For cell- and tissue-specific transductional targeting, nanoparticles can be decorated with anti-receptor sdAbs. Application of mRNA coding for cytosolic/nuclear single domain intrabodies might also be possible in the future. ${ }^{133,134}$

In summary, cytosolic/nuclear sdAbs of camelid, shark and human origin can be applied to clarify the function of uncharacterized proteins such as virus proteins and host cell factors, oncogenic proteins and cofactors, proteins of the nervous system, intracellular enzymes involved in signaling, transcription factors and proteins involved in differentiation and development.

\section{Acknowledgments}

Figures 1 and 2 were prepared by Oliver Backhaus. I thank Peter P Müller for reading the manuscript. Special thanks to S. Muyldermans and Wulf Blankenfeldt for critical reading the manuscript and giving very helpful comments.

\section{References}

1. Böldicke T (2015) Protein targeting compounds. Prediction, Selection and Activity of Specific Inhibitors. Springer Cham Heidelberg, New York.

2. Helma J, Cardoso MC, Muyldermans S, Leonhardt H (2015) Nanobodies and recombinant binders in cell biology. J Cell Biol 209:633-644.

3. Biocca S, Ruberti F, Tafani M, Pierandrei-Amaldi P, Cattaneo A (1995) Redox state of single chain Fv fragments targeted to the endoplasmic reticulum, cytosol and mitochondria. Biotechnology 13:1110-1115.

4. Wörn A, Plückthun A (2001) Stability engineering of antibody single-chain Fv fragments. J Mol Biol 305: 989-1010.

5. Visintin M, Settanni G, Maritan A, Graziosi S, Marks JD, Cattaneo A (2002) The intracellular antibody capture technology (IACT): towards a consensus sequence for intracellular antibodies. J Mol Biol 317:73-83.

6. Marschall AL, Dübel S, Böldicke T (2015) Specific in vivo knockdown of protein function by intrabodies. mAbs 7:1010-1035.

7. Muyldermans S (2013) Nanobodies: natural singledomain antibodies. Annu Rev Biochem 82:775-797.

8. Greenberg AS, Avila D, Hughes M, Hughes A, McKinney EC, Flajnik MF (1995) A new antigen receptor gene family that undergoes rearrangement and extensive somatic diversification in sharks. Nature 374:168-173.

9. Flajnik MF, Deschacht N, Muyldermans S (2011) A case of convergence: why did a simple alternative to canonical antibodies arise in sharks and camels?. PLoS Biol 9:e1001120.

10. Zielonka S, Empting M, Grzeschik J, Konning D, Barelle CJ, Kolmar H (2015) Structural insights and biomedical potential of IgNAR scaffolds from sharks. MAbs 7:15-25.
11. Liu JL, Zabetakis D, Brown JC, Anderson GP, Goldman ER (2014) Thermal stability and refolding capability of shark derived single domain antibodies. Mol Immunol 59:194-199.

12. Hairul Bahara NH, Chin ST, Choong YS, Lim TS (2016) Construction of a semisynthetic human VH single-domain antibody library and selection of domain antibodies against alpha-crystalline of Mycobacterium tuberculosis. J Biomol Screen 21:35-43.

13. Moutel S, Bery N, Bernard V, Keller L, Lemesre E, de Marco A, Ligat L, Rain JC, Favre G, Olichon A, Perez F (2016) NaLi-H1: A universal synthetic library of humanized nanobodies providing highly functional antibodies and intrabodies. Elife 5. pii: e16228. doi: 10.7554/eLife.16228

14. Christ D, Famm K, Winter G (2007) Repertoires of aggregation-resistant human antibody domains. Protein Eng Des Sel 20:413-416.

15. Mandrup OA, Friis NA, Lykkemark S, Just J, Kristensen P (2013) A novel heavy domain antibody library with functionally optimized complementarity determining regions. PLoS One 8:e76834.

16. Ignatovisch O, Jespers, L., Tomlinson, I.M., de Wildt, R.M.T., (2012) Creation of the Large and Highly Functional Synthetic Repertoire of Human $V H$ and $V_{\mathrm{K}}$ Domain Antibodies, in Saerens, D., Muyldermans (eds.) Single Domain Antibodies: Methods and Protocols, Springer, Methods in Molecular Biology, vol. 911, pp.39-63.

17. Hussack G, Keklikian A, Alsughayyir J, HanifiMoghaddam P, Arbabi-Ghahroudi M, van Faassen H, Hou ST, Sad S, MacKenzie R, Tanha J (2012) A V(L) single-domain antibody library shows a highpropensity to yield non-aggregating binders. Protein Eng Des Sel 25:313-318.

18. Soderlind E, Vergeles M, Borrebaeck CA (1995) Domain libraries: synthetic diversity for de novo design of antibody V-regions. Gene 160:269-272.

19. Traenkle B, Emele F, Anton R, Poetz O, Haeussler RS, Maier J, Kaiser PD, Scholz AM, Nueske S, Buchfellner A, Romer T, Rothbauer U (2015) Monitoring interactions and dynamics of endogenous beta-catenin with intracellular nanobodies in living cells. Mol Cell Proteomics 14:707-723.

20. Panza P, Maier J, Schmees C, Rothbauer U, Sollner C (2015) Live imaging of endogenous protein dynamics in zebrafish using chromobodies. Development 142:18791884.

21. Staus DP, Wingler LM, Strachan RT, Rasmussen SG, Pardon E, Ahn S, Steyaert J, Kobilka BK, Lefkowitz RJ (2014) Regulation of beta2-adrenergic receptor function by conformationally selective single-domain intrabodies. Mol Pharmacol 85:472-481.

22. Rajan M, Mortusewicz O, Rothbauer U, Hastert FD, Schmidthals K, Rapp A, Leonhardt H, Cardoso MC (2015) Generation of an alpaca-derived nanobody recognizing gamma-H2AX. FEBS Open Bio 5:779-788.

23. Desmyter A, Spinelli S, Roussel A, Cambillau C (2015) Camelid nanobodies: killing two birds with one stone. Curr Opin Struct Biol 32:1-8.

24. Revets H, De Baetselier P, Muyldermans S (2005) Nanobodies as novel agents for cancer therapy. Expert Opin Biol Ther 5:111-124.

25. Monegal A, Ami D, Martinelli C, Huang H, Aliprandi M, Capasso P, Francavilla C, Ossolengo G, de Marco A (2009) Immunological applications of single-domain llama recombinant antibodies isolated from a naive library. Protein Eng Des Sel 22:273-280. 
26. Yan J, Wang P, Zhu M, Li G, Romao E, Xiong S, Wan Y (2015) Characterization and applications of Nanobodies against human procalcitonin selected from a novel naive Nanobody phage display library. J Nanobiotechnology 13:33.

27. Yau KY, Groves MA, Li S, Sheedy C, Lee H, Tanha J, MacKenzie CR, Jermutus L, Hall JC (2003) Selection of hapten-specific single-domain antibodies from a nonimmunized llama ribosome display library. J Immunol Methods 281:161-175.

28. Konning D, Zielonka S, Sellmann C, Schroter C, Grzeschik J, Becker S, Kolmar H (2016) Isolation of a $\mathrm{pH}$-Sensitive IgNAR Variable Domain from a YeastDisplayed, Histidine-Doped Master Library. Mar Biotechnol 18:161-167.

29. Liu JL, Anderson GP, Goldman ER (2007) Isolation of anti-toxin single domain antibodies from a semisynthetic spiny dogfish shark display library. BMC Biotechnol 7:78.

30. Nuttall SD, Krishnan UV, Doughty L, Pearson K, Ryan MT, Hoogenraad NJ, Hattarki M, Carmichael JA, Irving RA, Hudson PJ (2003) Isolation and characterization of an IgNAR variable domain specific for the human mitochondrial translocase receptor Tom70. Eur J Biochem 270:3543-3554.

31. Nuttall SD, Krishnan UV, Hattarki M, De Gori R, Irving RA, Hudson PJ (2001) Isolation of the new antigen receptor from wobbegong sharks, and use as a scaffold for the display of protein loop libraries. Mol Immunol 38:313-326.

32. Ohtani M, Hikima J, Jung TS, Kondo H, Hirono I, Aoki T (2013) Construction of an artificially randomized IgNAR phage display library: screening of variable regions that bind to hen egg white lysozyme. Mar Biotechnol 15:56-62.

33. Shao CY, Secombes CJ, Porter AJ (2007) Rapid isolation of IgNAR variable single-domain antibody fragments from a shark synthetic library. Mol Immunol 44: 656-665.

34. Hasler J, Flajnik MF, Williams G, Walsh FS, Rutkowski JL (2016) VNAR single-domain antibodies specific for BAFF inhibit B cell development by molecular mimicry. Mol Immunol 75:28-37.

35. Van Roy M, Ververken C, Beirnaert E, Hoefman S, Kolkman J, Vierboom M, Breedveld E, t Hart B, Poelmans S, Bontinck L, Hemeryck A, Jacobs S, Baumeister J, Ulrichts H (2015) The preclinical pharmacology of the high affinity anti-IL-6R Nanobody(R) ALX-0061 supports its clinical development in rheumatoid arthritis. Arthritis Res Ther 17:135.

36. Yau KY, Dubuc G, Li S, Hirama T, Mackenzie CR, Jermutus L, Hall JC, Tanha J (2005) Affinity maturation of a $\mathrm{V}(\mathrm{H}) \mathrm{H}$ by mutational hotspot randomization. J Immunol Methods 297:213-224.

37. Shahi B, Mousavi Gargari SL, Rasooli I, Rajabi Bazl M, Hoseinpoor R (2014) Random mutagenesis of BoNT/ E Hc nanobody to construct a secondary phage-display library. J Appl Microbiol 117:528-536.

38. Vercruysse T, Pardon E, Vanstreels E, Steyaert J, Daelemans D (2010) An intrabody based on a llama single-domain antibody targeting the $\mathrm{N}$-terminal alpha-helical multimerization domain of HIV-1 rev prevents viral production. J Biol Chem 285:21768-21780.

39. Boons $\mathrm{E}$, $\mathrm{Li} \mathrm{G}$, Vanstreels $\mathrm{E}$, Vercruysse $\mathrm{T}$, Pannecouque C, Vandamme AM, Daelemans D (2014) A stably expressed llama single-domain intrabody targeting Rev displays broad-spectrum anti-HIV activity. Antiviral Res 112:91-102.
40. Matz J, Herate C, Bouchet J, Dusetti N, Gayet O, Baty D, Benichou S, Chames P (2014) Selection of intracellular single-domain antibodies targeting the HIV-1 Vpr protein by cytoplasmic yeast two-hybrid system. PLoS One 9:e113729.

41. Aires da Silva F, Santa-Marta M, Freitas-Vieira A Mascarenhas P, Barahona I, Moniz-Pereira J, Gabuzda D, Goncalves J (2004) Camelized rabbit-derived VH single-domain intrabodies against Vif strongly neutralize HIV-1 infectivity. J Mol Biol 340:525-542.

42. Bouchet J, Basmaciogullari SE, Chrobak P, Stolp B, Bouchard N, Fackler OT, Chames P, Jolicoeur P, Benichou S, Baty D (2011) Inhibition of the Nef regulatory protein of HIV-1 by a single-domain antibody. Blood 117:3559-3568.

43. Bouchet J, Herate C, Guenzel CA, Verollet C, Jarviluoma A, Mazzolini J, Rafie S, Chames P, Baty D, Saksela K, Niedergang F, Maridonneau-Parini I, Benichou S (2012) Single-domain antibody-SH3 fusions for efficient neutralization of HIV-1 Nef functions. J Virol 86:4856-4867.

44. Ashour J, Schmidt FI, Hanke L, Cragnolini J, Cavallari M, Altenburg A, Brewer R, Ingram J, Shoemaker C, Ploegh HL (2015) Intracellular expression of camelid single-domain antibodies specific for influenza virus nucleoprotein uncovers distinct features of its nuclear localization. J Virol 89:2792-2800.

45. Glab-Ampai K, Malik AA, Chulanetra M, Thanongsaksrikul J, Thueng-In K, Srimanote P, Tongtawe P, Chaicumpa W (2016) Inhibition of HCV replication by humanized-single domain transbodies to NS4B. Biochem Biophys Res Commun 476:654-664.

46. Phalaphol A, Thueng-In K, Thanongsaksrikul J, Poungpair O, Bangphoomi K, Sookrung N, Srimanote P, Chaicumpa W (2013) Humanized-VH/VHH that inhibit HCV replication by interfering with the virus helicase activity. J Virol Methods 194:289-299.

47. Thueng-in K, Thanongsaksrikul J, Srimanote $P$, Bangphoomi K, Poungpair O, Maneewatch S, Choowongkomon K, Chaicumpa W (2012) Cell penetrable humanized- $\mathrm{VH} / \mathrm{V}(\mathrm{H}) \mathrm{H}$ that inhibit RNA dependent RNA polymerase (NS5B) of HCV. PLoS One 7:e49254.

48. Suzuki R, Saito K, Matsuda M, Sato M, Kanegae Y, Shi G, Watashi K, Aizaki H, Chiba J, Saito I, Wakita T, Suzuki T (2016) Single-domain intrabodies against hepatitis $\mathrm{C}$ virus core inhibit viral propagation and core-induced NFkappaB activation. J Gen Virol 97: 887-892.

49. Serruys B, Van Houtte F, Farhoudi-Moghadam A, Leroux-Roels G, Vanlandschoot P (2010) Production, characterization and in vitro testing of $\mathrm{HBcAg}$-specific VHH intrabodies. J Gen Virol 91:643-652.

50. Liu H, Wang Y, Duan H, Zhang A, Liang C, Gao J, Zhang C, Huang B, Li Q, Li N, Xiao S, Zhou EM (2015) An intracellularly expressed Nsp9-specific nanobody in MARC-145 cells inhibits porcine reproductive and respiratory syndrome virus replication. Vet Microbiol 181:252-260.

51. Liu H, Liang C, Duan H, Zhang X, Wang X, Xiao S, Zhou EM (2016) Intracellularly expressed nanobodies against non-structural protein 4 of porcine reproductive and respiratory syndrome virus inhibit virus replication. Biotechnol Lett 38:1081-1088.

52. Dekker S, Toussaint W, Panayotou G, de Wit T, Visser P, Grosveld F, Drabek D (2003) Intracellularly expressed single-domain antibody against p15 matrix protein prevents the production of porcine retroviruses. J Virol 77:12132-12139. 
53. Alzogaray V, Danquah W, Aguirre A, Urrutia M, Berguer P, Garcia Vescovi E, Haag F, Koch-Nolte F, Goldbaum FA (2011) Single-domain llama antibodies as specific intracellular inhibitors of SpvB, the actin ADPribosylating toxin of Salmonella typhimurium. FASEB J 25:526-534.

54. Tremblay JM, Kuo CL, Abeijon C, Sepulveda J, Oyler G, Hu X, Jin MM, Shoemaker CB (2010) Camelid single domain antibodies (VHHs) as neuronal cell intrabody binding agents and inhibitors of Clostridium botulinum neurotoxin (BoNT) proteases. Toxicon 56: 990-998.

55. Doyle PJ, Saeed H, Hermans A, Gleddie SC, Hussack G, Arbabi-Ghahroudi M, Seguin C, Savard ME, Mackenzie CR, Hall JC (2009) Intracellular expression of a single domain antibody reduces cytotoxicity of 15acetyldeoxynivalenol in yeast. J Biol Chem 284:3502935039 .

56. Zeng J, Li HC, Tanaka T, Rabbitts TH (2015) Selection of human single domain antibodies recognizing the CMYC protein using enhanced intracellular antibody capture. J Immunol Methods 426:140-143.

57. Tanaka T, Sewell H, Waters S, Phillips SE, Rabbitts TH (2011) Single domain intracellular antibodies from diverse libraries: emphasizing dual functions of LMO2 protein interactions using a single $\mathrm{VH}$ domain. J Biol Chem 286:3707-3716.

58. Paz K, Brennan LA, Iacolina M, Doody J, Hadari YR, Zhu Z (2005) Human single-domain neutralizing intrabodies directed against Etk kinase: a novel approach to impair cellular transformation. Mol Cancer Ther 4: 1801-1809.

59. Summanen M, Granqvist N, Tuominen RK, Yliperttula M, Verrips CT, Boonstra J, Blanchetot C, Ekokoski E (2012) Kinetics of PKCepsilon activating and inhibiting llama single chain antibodies and their effect on PKCepsilon translocation in HeLa cells. PLoS One 7: e35630.

60. Van Impe K, Bethuyne J, Cool S, Impens F, RuanoGallego D, De Wever O, Vanloo B, Van Troys M, Lambein K, Boucherie C, Martens E, Zwaenepoel O, Hassanzadeh-Ghassabeh G, Vandekerckhove J, Gevaert K, Fernandez LA, Sanders NN, Gettemans J (2013) A nanobody targeting the F-actin capping protein CapG restrains breast cancer metastasis. Breast Cancer Res 15:R116.

61. Tanaka T, Rabbitts TH (2003) Intrabodies based on intracellular capture frameworks that bind the RAS protein with high affinity and impair oncogenic transformation. embo J 22:1025-1035.

62. McGonigal K, Tanha J, Palazov E, Li S, GueorguievaOwens D, Pandey S (2009) Isolation and functional characterization of single domain antibody modulators of Caspase-3 and apoptosis. Appl Biochem Biotechnol 157:226-236.

63. Inoue A, Sawata SY, Taira K, Wadhwa R (2007) Lossof-function screening by randomized intracellular antibodies: identification of hnRNP-K as a potential target for metastasis. Proc Natl Acad Sci USA 104:8983-8988.

64. Gueorguieva D, Li S, Walsh N, Mukerji A, Tanha J, Pandey S (2006) Identification of single-domain, Baxspecific intrabodies that confer resistance to mammalian cells against oxidative-stress-induced apoptosis. FASEB J 20:2636-2638.

65. Delanote V, Vanloo B, Catillon M, Friederich E, Vandekerckhove J, Gettemans J (2010) An alpaca single-domain antibody blocks filopodia formation by obstructing L-plastin-mediated F-actin bundling. FASEB J 24:105-118.
66. De Clercq S, Boucherie C, Vandekerckhove J, Gettemans J, Guillabert A (2013) L-plastin nanobodies perturb matrix degradation, podosome formation, stability and lifetime in THP-1 macrophages. PloS one 8:e78108.

67. De Clercq S, Zwaenepoel O, Martens E, Vandekerckhove J, Guillabert A, Gettemans J (2013) Nanobody-induced perturbation of LFA-1/L-plastin phosphorylation impairs MTOC docking, immune synapse formation and T cell activation. Cell Mol Life Sci 70:909.

68. Van Audenhove I, Boucherie C, Pieters L, Zwaenepoel O, Vanloo B, Martens E, Verbrugge C, HassanzadehGhassabeh G, Vandekerckhove J, Cornelissen M, De Ganck A, Gettemans J (2014) Stratifying fascin and cortactin function in invadopodium formation using inhibitory nanobodies and targeted subcellular delocalization. FASEB J 28:1805-1818.

69. Van den Abbeele A, De Clercq S, De Ganck A, De Corte V, Van Loo B, Soror SH, Srinivasan V, Steyaert J, Vandekerckhove J, Gettemans J (2010) A llamaderived gelsolin single-domain antibody blocks gelsolinG-actin interaction. Cell Mol Life Sci 67:1519-1535.

70. Colby DW, Garg P, Holden T, Chao G, Webster JM, Messer A, Ingram VM, Wittrup KD (2004) Development of a human light chain variable domain $(\mathrm{V}(\mathrm{L}))$ intracellular antibody specific for the amino terminus of huntingtin via yeast surface display. J Mol Biol 342:901-912.

71. Colby DW, Chu Y, Cassady JP, Duennwald M, Zazulak $\mathrm{H}$, Webster JM, Messer A, Lindquist S, Ingram VM, Wittrup KD (2004) Potent inhibition of huntingtin aggregation and cytotoxicity by a disulfide bond-free single-domain intracellular antibody. Proc Natl Acad Sci USA 101:17616-17621.

72. Lynch SM, Zhou C, Messer A (2008) An scFv intrabody against the nonamyloid component of alpha-synuclein reduces intracellular aggregation and toxicity. $\mathrm{J}$ Mol Biol 377:136-147.

73. Joshi SN, Butler DC, Messer A (2012) Fusion to a highly charged proteasomal retargeting sequence increases soluble cytoplasmic expression and efficacy of diverse anti-synuclein intrabodies. MAbs 4:686-693.

74. Newnham LE, Wright MJ, Holdsworth G, Kostarelos K, Robinson MK, Rabbitts TH, Lawson AD (2015) Functional inhibition of beta-catenin-mediatedWnt signaling by intracellular VHHantibodies. MAbs 7:180-191.

75. Verheesen $P$, de Kluijver A, van Koningsbruggen S, de Brij M, de Haard HJ, van Ommen GJ, van der Maarel SM, Verrips CT (2006) Prevention of oculopharyngeal muscular dystrophy-associated aggregation of nuclear polyA-binding protein with a single-domain intracellular antibody. Hum Mol Genet 15:105-111.

76. Jimenez JI, Fraile S, Zafra O, de Lorenzo V (2015) Phenotypic knockouts of selected metabolic pathways by targeting enzymes with camel-derived nanobodies $(\mathrm{V}(\mathrm{HH}) \mathrm{s})$. Metab Eng 30:40-48.

77. Jobling SA, Jarman C, Teh MM, Holmberg N, Blake C, Verhoeyen ME (2003) Immunomodulation of enzyme function in plants by single-domain antibody fragments. Nat Biotechnol 21:77-80.

78. Bouaziz D, Ayadi M, Bidani A, Rouis S, Nouri-Ellouz O, Jellouli R, Drira N, Gargouri-Bouzid R (2009) A stable cytosolic expression of $\mathrm{VH}$ antibody fragment directed against PVY NIa protein in transgenic potato plant confers partial protection against the virus. Plant Sci 176:489-496.

79. Caussinus E, Kanca O, Affolter M (2012) Fluorescent fusion protein knockout mediated by anti-GFP nanobody. Nat Struct Mol Biol 19:117-121.

80. Harmansa S, Hamaratoglu F, Affolter M, Caussinus E (2015) Dpp spreading is required for medial but not for lateral wing disc growth. Nature 527:317-322. 
81. Tanaka T, Williams RL, Rabbitts TH (2007) Tumour prevention by a single antibody domain targeting the interaction of signal transduction proteins with RAS. EMBO J 26:3250-3259.

82. Marschall AL, Single FN, Schlarmann K, Bosio A, Strebe N, van den Heuvel J, Frenzel A, Dübel S (2014) Functional knock down of VCAM1 in mice mediated by endoplasmatic reticulum retained intrabodies. MAbs 6: [PAGE \#].

83. Marschall AL, Dubel S, Boldicke T (2016) Recent advances with ER targeted intrabodies. Adv Exp Med Biol 917:77-93.

84. Böldicke T (2007) Blocking translocation of cell surface molecules from the ER to the cell surface by intracellular antibodies targeted to the ER. J Cell Mol Med 11: 54-70.

85. Böldicke T, Somplatzki S, Sergeev G, Mueller PP (2012) Functional inhibition of transitory proteins by intrabody-mediated retention in the endoplasmatic reticulum. Methods 56:338-350.

86. van Anken E, Braakman I (2005) Versatility of the endoplasmic reticulum protein folding factory. Crit Rev Biochem Mol Biol 40:191-228.

87. De Meyer T, Muyldermans S, Depicker A (2014) Nanobody-based products as research and diagnostic tools. Trends Biotechnol 32:263-270.

88. Van Audenhove I, Gettemans J (2016) Nanobodies as versatile tools to understand, diagnose, visualize and treat cancer. EBioMedicine 8:40-48.

89. Amici C, Visintin M, Verachi F, Paolini F, Percario Z, Di Bonito P, Mandarino A, Affabris E, Venuti A, Accardi L (2016) A novel intracellular antibody against the E6 oncoprotein impairs growth of human papillomavirus 16-positive tumor cells in mouse models. Oncotarget 7:15539-15553.

90. Chan G, Jordaan G, Nishimura RN, Weisbart RH (2016) Combining intracellular antibodies to restore function of mutated p53 in cancer. Int $\mathrm{J}$ Cancer 138: 182-186.

91. Arbabi Ghahroudi M, Desmyter A, Wyns L, Hamers R, Muyldermans S (1997) Selection and identification of single domain antibody fragments from camel heavychain antibodies. FEBS Lett 414:521-526.

92. Verheesen P, Roussis A, de Haard HJ, Groot AJ, Stam JC, den Dunnen JT, Frants RR, Verkleij AJ, Theo Verrips C, van der Maarel SM (2006) Reliable and controllable antibody fragment selections from Camelid non-immune libraries for target validation. Biochim Biophys Acta 1764:1307-1319.

93. Sabir JS, Atef A, El-Domyati FM, Edris S, Hajrah N, Alzohairy AM, Bahieldin A (2014) Construction of naive camelids VHH repertoire in phage display-based library. C R Biol 337:244-249.

94. Bencurova E, Pulzova L, Flachbartova Z, Bhide M (2015) A rapid and simple pipeline for synthesis of mRNA-ribosome- $\mathrm{V}(\mathrm{H}) \mathrm{H}$ complexes used in singledomain antibody ribosome display. Mol Biosyst 11: 1515-1524.

95. Yan J, Li G, Hu Y, Ou W, Wan Y (2014) Construction of a synthetic phage-displayed Nanobody library with CDR3 regions randomized by trinucleotide cassettes for diagnostic applications. J Transl Med 12:343.

96. Goldman ER, Anderson GP, Liu JL, Delehanty JB, Sherwood LJ, Osborn LE, Cummins LB, Hayhurst A (2006) Facile generation of heat-stable antiviral and antitoxin single domain antibodies from a semisynthetic llama library. Anal Chem 78:8245-8255.

97. Sherwood LJ, Hayhurst A (2013) Ebolavirus nucleoprotein C-termini potently attract single domain antibodies enabling monoclonal affinity reagent sandwich assay (MARSA) formulation. PLoS One 8:e61232.

98. Saerens D, Pellis M, Loris R, Pardon E, Dumoulin M, Matagne A, Wyns L, Muyldermans S, Conrath K (2005) Identification of a universal VHH framework to graft non-canonical antigen-binding loops of camel single-domain antibodies. J Mol Biol 352:597-607.

99. Reiter Y, Schuck P, Boyd LF, Plaksin D (1999) An antibody single-domain phage display library of a native heavy chain variable region: isolation of functional single-domain VH molecules with a unique interface. J Mol Biol 290:685-698.

100. Griffiths K, Dolezal O, Cao B, Nilsson SK, See HB, Pfleger KD, Roche M, Gorry PR, Pow A, Viduka K, Lim K, Lu BG, Chang DH, Murray-Rust T, Kvansakul M, Perugini MA, Dogovski C, Doerflinger M, Zhang Y, Parisi K, Casey JL, Nuttall SD, Foley M (2016) i-bodies, human single domain antibodies that antagonize chemokine receptor CXCR4. J Biol Chem 291:12641-12657.

101. Tanha J, Nguyen TD, Ng A, Ryan S, Ni F, Mackenzie $\mathrm{R}$ (2006) Improving solubility and refolding efficiency of human $\mathrm{V}(\mathrm{H})$ s by a novel mutational approach. Protein Eng Des Sel 19:503-509.

102. Tanha J, Xu P, Chen Z, Ni F, Kaplan H, Narang SA, MacKenzie CR (2001) Optimal design features of camelized human single-domain antibody libraries. J Biol Chem 276:24774-24780.

103. Schmidt FI, Hanke L, Morin B, Brewer R, Brusic V, Whelan SP, Ploegh HL (2016) Phenotypic lentivirus screens to identify functional single domain antibodies. Nat Microbiol 1:16080.

104. Tanaka T, Rabbitts TH (2012) Intracellular antibody capture (IAC) methods for single domain antibodies. Methods Mol Biol 911:151-173.

105. Tanaka T, Rabbitts TH (2010) Protocol for the selection of single-domain antibody fragments by third generation intracellular antibody capture. Nat Protoc 5:67-92.

106. Pellis M, Pardon E, Zolghadr K, Rothbauer U, Vincke C, Kinne J, Dierynck I, Hertogs $\mathrm{K}$, Leonhardt H, Messens J, Muyldermans S, Conrath K (2012) A bacterial-two-hybrid selection system for one-step isolation of intracellularly functional Nanobodies. Arch Biochem Biophys 526:114-123.

107. Zolghadr K, Mortusewicz O, Rothbauer U, Kleinhans R, Goehler H, Wanker EE, Cardoso MC, Leonhardt H (2008) A fluorescent two-hybrid assay for direct visualization of protein interactions in living cells. Mol Cell Proteomics 7:2279-2287.

108. Lee WR, Jang JY, Kim JS, Kwon MH, Kim YS (2010) Gene silencing by cell-penetrating, sequence-selective and nucleic-acid hydrolyzing antibodies. Nucleic Acids Res 38:1596-1609.

109. Marschall AL, Zhang C, Frenzel A, Schirrmann T, Hust M, Perez F, Dübel S (2014) Delivery of antibodies to the cytosol: debunking the myths. MAbs 6 : 943-956.

110. Marschall AL, Frenzel A, Schirrmann T, Schüngel M, Dübel S (2011) Targeting antibodies to the cytoplasm. MAbs 3:3-16.

111. Salerno JC, Ngwa VM, Nowak SJ, Chrestensen CA, Healey AN, McMurry JL (2016) Novel cell-penetrating peptide-adaptors effect intracellular delivery and endosomal escape of protein cargos. J Cell Sci 129: 893-897.

112. Dixon JE, Osman G, Morris GE, Markides H, Rotherham M, Bayoussef Z, El Haj AJ, Denning C, Shakesheff KM (2016) Highly efficient delivery of 
functional cargoes by the synergistic effect of GAG binding motifs and cell-penetrating peptides. Proc Natl Acad Sci USA 113:E291-E299.

113. Jittavisutthikul S, Thanongsaksrikul J, Thueng-In K, Chulanetra M, Srimanote P, Seesuay W, Malik AA, Chaicumpa W (2015) Humanized-VHH transbodies that inhibit HCV protease and replication. Viruses 7: 2030-2056.

114. Ravindran S, Snee PT, Ramachandran A, George A (2013) Acidic domain in dentin phosphophoryn facilitates cellular uptake: implications in targeted protein delivery. J Biol Chem 288:16098-16109.

115. Zhang N, Yan Z, Zhao X, Chen Q, Ma M (2016) An efficient mini-transporter for cytosolic protein delivery. ACS Appl Mater Interfaces [VOL:PAGE \#S].

116. Lonn P, Kacsinta AD, Cui XS, Hamil AS, Kaulich M, Gogoi K, Dowdy SF (2016) Enhancing endosomal escape for intracellular delivery of macromolecular biologic therapeutics. Sci Rep 6:32301.

117. Qian Z, Martyna A, Hard RL, Wang J, Appiah-Kubi G, Coss C, Phelps MA, Rossman JS, Pei D (2016) Discovery and mechanism of highly efficient cyclic cellpenetrating peptides. Biochemistry 55:2601-2612.

118. Bruce VJ, Lopez-Islas M, McNaughton BR (2016) Resurfaced cell-penetrating nanobodies: A potentially general scaffold for intracellularly targeted protein discovery. Protein Sci 25:1129-1137.

119. Blanco-Toribio A, Muyldermans S, Frankel G, Fernandez LA (2010) Direct injection of functional single-domain antibodies from E. coli into human cells. PLoS One 5:e15227.

120. Zou T, Dembele F, Beugnet A, Sengmanivong L, Trepout S, Marco S, de Marco A, Li MH (2015) Nanobody-functionalized PEG-b-PCL polymersomes and their targeting study. J Biotechnol 214:147-155.

121. Sadeqzadeh E, Rahbarizadeh F, Ahmadvand D, Rasaee MJ, Parhamifar L, Moghimi SM (2011) Combined MUC1-specific nanobody-tagged PEGpolyethylenimine polyplex targeting and transcriptional targeting of tBid transgene for directed killing of MUC1 over-expressing tumour cells. J Control Release 156:85-91.

122. Bian $\mathrm{X}$, Wu $\mathrm{P}$, Sha H, Qian H, Wang Q, Cheng L, Yang Y, Yang M, Liu B (2016) Anti-EGFR-iRGD recombinant protein conjugated silk fibroin nanoparticles for enhanced tumor targeting and antitumor efficiency. Onco Targets Ther 9:3153-3162.
123. Kafa H, Wang JT, Rubio N, Klippstein R, Costa PM, Hassan HA, Sosabowski JK, Bansal SS, Preston JE, Abbott NJ, Al-Jamal KT (2016) Translocation of LRP1 targeted carbon nanotubes of different diameters across the blood-brain barrier in vitro and in vivo. J Control Release 225:217-229.

124. Yan F, Wang Y, He S, Ku S, Gu W, Ye L (2013) Transferrin-conjugated, fluorescein-loaded magnetic nanoparticles for targeted delivery across the blood-brain barrier. J Mater Sci Mater Med 24:2371-2379.

125. Oku T, Ando Y, Ogura M, Tsuji T (2016) Development of splice variant-specific monoclonal antibodies against human alpha3 integrin. Monoclon Antib Immunodiagn Immunother 35:12-17.

126. D'Amico AG, Maugeri G, Reitano R, Cavallaro S, D'Agata V (2016) Proteomic analysis of parkin isoforms expression in different rat brain areas. Protein J [VOL:PAGE \#S].

127. Koo MY, Park J, Lim JM, Joo SY, Shin SP, Shim HB, Chung J, Kang D, Woo HA, Rhee SG (2014) Selective inhibition of the function of tyrosine-phosphorylated STAT3 with a phosphorylation site-specific intrabody. Proc Natl Acad Sci USA 111:6269-6274.

128. Dorsett Y, Tuschl T (2004) siRNAs: applications in functional genomics and potential as therapeutics. Nat Rev Drug Discov 3:318-329.

129. Behlke MA (2008) Chemical modification of siRNAs for in vivo use. Oligonucleotides 18:305-319.

130. Hu J, Liu J, Corey DR (2010) Allele-selective inhibition of huntingtin expression by switching to an miRNA-like RNAi mechanism. Chem Biol 17:11831188.

131. Martinez LA, Naguibneva I, Lehrmann H, Vervisch A, Tchenio T, Lozano G, Harel-Bellan A (2002) Synthetic small inhibiting RNAs: efficient tools to inactivate oncogenic mutations and restore p53 pathways. Proc Natl Acad Sci USA 99:14849-14854.

132. Wei G, Meng W, Guo H, Pan W, Liu J, Peng T, Chen L, Chen CY (2011) Potent neutralization of influenza A virus by a single-domain antibody blocking M2 ion channel protein. PLoS One 6:e28309.

133. Kallen KJ, Thess A (2014) A development that may evolve into a revolution in medicine: mRNA as the basis for novel, nucleotide-based vaccines and drugs. Ther Adv Vaccines 2:10-31.

134. Dolgin E (2015) Business: The billion-dollar biotech Nature 522:26-28. 